\title{
Effect of Dispersoids and Intermetallics on Hardening the Al-Si-Cu-Mg Cast Alloys
}

\author{
J. Hernandez-Sandoval, ${ }^{1}$ M. H. Abdelaziz $\left(\mathbb{D},{ }^{2}\right.$ A. M. Samuel $\mathbb{D}^{3},{ }^{3}$ H. W. Doty, ${ }^{4}$ \\ and F. H. Samuel $\left.{ }^{3}\right)^{3}$ \\ ${ }^{1}$ Facultad de Ingeniería Mecánica y Eléctrica, Universidad Autónoma de Nuevo Leon, San Nicolás de los Garza, Mexico \\ ${ }^{2}$ Département PEC, Université Française d'Egypte, El Shorouk, Le Caire, Egypt \\ ${ }^{3}$ Département des Sciences Appliquées, Université du Québec à Chicoutimi, Saguenay, Canada \\ ${ }^{4}$ General Motors Materials Engineering, Warren, MI 48340, USA
}

Correspondence should be addressed to F. H. Samuel; fhsamuel@uqac.ca

Received 14 March 2021; Accepted 28 April 2021; Published 11 May 2021

Academic Editor: Jörg M. K. Wiezorek

Copyright $(2021$ J. Hernandez-Sandoval et al. This is an open access article distributed under the Creative Commons Attribution License, which permits unrestricted use, distribution, and reproduction in any medium, provided the original work is properly cited.

\begin{abstract}
The principal aim of the present research work was to compare the role of dispersoids $\mathrm{Al}_{2} \mathrm{O}_{3}(\sim 15 \mu \mathrm{m}$ average particle size) and SiC ( $\sim 15 \mu \mathrm{m}$ average particle size) with that offered by $\mathrm{Zr}$ - and Ni-based intermetallics $(\sim 35-70 \mu \mathrm{m}$ average particle size) on the hardening of cast aluminum 354 alloy $(9.1 \% \mathrm{Si}, 0.12 \% \mathrm{Fe}, 1.8 \% \mathrm{Cu}, 0.008 \% \mathrm{Mn}, 0.6 \% \mathrm{Mg}$, and $87.6 \% \mathrm{Al})$ at ambient temperature. There is no observable poisoning effect on the refinement of grain size after the addition of $\mathrm{Zr}$ to the alloys investigated in this study. The tensile test results were examined in light of the microstructural features of the corresponding alloy samples. The contribution of the added dispersoids or $\mathrm{Ni}$ and $\mathrm{Zr}$ alloying elements on the tensile properties of the 354 alloys was determined employing $\triangle \mathrm{P}$ plots (where $\mathrm{P}=$ Property, UTS, YS, or $\% \mathrm{El}$ ), using the base alloy (in the as-cast condition) as a reference point. The tensile results were supported by investigating the precipitation-hardening phases using scanning and transmission electron microscopy as well as examining the fracture surfaces of selected conditions applying field emission scanning electron microscopy. The results show that, in all cases, $\mathrm{Al}_{2} \mathrm{Cu}$ phase is the main hardening agent. The contribution of about 1.5 vol\% of $\mathrm{SiC}_{\mathrm{C}} \mathrm{Al}_{2} \mathrm{O}_{3}$ to the strength of the base alloy is higher than that offered by Zr- and Ni-based intermetallics, under the same aging treatment.
\end{abstract}

\section{Introduction}

Dispersoids are defined as small and numerous finely divided particles of one substance dispersed in another. Dispersoid particles are normally hard and brittle, resulting in excellent dispersion strengthening of the softer aluminum matrix [1]. According to Srinivasan and Imam [2], dispersoids are thermodynamically stable second-phase particles. Their size is in the range of 0.1 to $1.0 \mu \mathrm{m}$, which is made use of to reduce the alloy grain size. Fracture of these particles under loading can lead to the nucleation of cracks ahead of the main advancing crack. The effect of $\mathrm{Cr}$ and $\mathrm{Mn}$ addition and heat treatment on AlSi3Mg casting alloy was investigated by Tocci et al. [3] who found that Cr- and Mn-based dispersoid particles improve Vickers microhardness of the aluminum matrix compared to the base alloy after solution treatment and quenching, which is in accordance with the dispersion-hardening mechanism. In a similar study, Remøe et al. [4] recommended decreasing heating rates which would increase the dispersoid density.

Dispersoids were also described as particles that form during ingot preheating caused by precipitation of the transition elements $\mathrm{Cr}, \mathrm{Mn}$, or $\mathrm{Zr}$ in the form of $\mathrm{Al}_{12} \mathrm{Mg}_{2} \mathrm{Cr}$, $\mathrm{Al}_{20} \mathrm{Cu}_{2} \mathrm{Mn}_{3}$, or $\mathrm{Al}_{12} \mathrm{Mn}_{3} \mathrm{Si}$ and $\mathrm{Al}_{3} \mathrm{Zr}$ particles, respectively [5]. A significant increase in mechanical properties of the tested hypoeutectic alloys was obtained by supersaturation of the Al phase with high melting point elements during HPDC processing of AlSi9Cu3 $(\mathrm{Fe})$ alloy as reported by Szymczak et al. [6]. A study of dispersoid particles in two $\mathrm{Al}-\mathrm{Mg}-\mathrm{Si}$ 6xxx-type aluminum alloys and their effects on 
the recrystallization was conducted by Hichem and Rebai [7]. Their main conclusion was that the incorporation of $\mathrm{Si}$ in the metastable $\mathrm{Al}_{3} \mathrm{Zr}$ type of dispersoid particles could increase the nucleation rate by reducing the volume-free energy of formation of the dispersoid particles. Kenyon et al. [8] added that changing the dispersoid volume fraction, size, and morphology has important implications for the pinning effectiveness of the dispersoids.

It is necessary to produce a microstructure containing thermally stable and coarsening-resistant dispersoids in order to enhance the mechanical properties of an aluminum alloy, in particular at high temperatures. The dispersoids or particles play an important role in resisting coarsening if the energy of their interface with the matrix, diffusivity, and solubility is low. The $\mathrm{Al}_{3} \mathrm{Zr}$ particles are resistant to dissolution and coarsening; they can also control the evolution of the grain and subgrain structure, thereby making it possible to increase strength and ductility in the precipitationhardened T6 condition [9-12]. The effectiveness of the dispersoids depends on their size, spacing, and distribution. In direct-chill cast alloys, the alloying elements are highly segregated following solidification [13-15].

According to Szajewski et al. [16], three different types of dislocation-precipitate interactions could occur depending on the nature of the precipitates, i.e., whether they are coherent or noncoherent. Strengthening by coherent precipitates is caused by distortion in the crystal lattice, representing barriers to dislocation movement [17-20]. Several research articles $[6,8,21-23]$ emphasized that binary dispersoids such as $\mathrm{Al}_{3} \mathrm{Zr}$ can be less effective due to limitations encountered during conventional manufacturing processes. Improvements can be achieved through the transformation of these binary trialuminides into ternary or quaternary forms by alloying with appropriate elements.

Previously, the present authors discussed the effect of addition of $\mathrm{SiC}$ and $\mathrm{Al}_{2} \mathrm{O}_{3}$ particulates on the microstructure and tensile properties (mainly quality index values as a function of thermal treatment) of $\mathrm{Al}-\mathrm{Si}-\mathrm{Cu}-\mathrm{Mg}$ cast alloys [23]. In addition, the authors analyzed the effect of different alloying elements on the performance of this family of alloys over several publications [24-28]. The subject was readdressed in the present work to highlight the difference in the effectiveness of dispersoids, mainly $\mathrm{Al}_{2} \mathrm{O}_{3}, \mathrm{SiC}$ and $\mathrm{Al}_{3} \mathrm{Zr}$, compared to intermetallics offered by the addition of $\mathrm{Zr}$ and $\mathrm{Ni}$ in the amounts of $0.25 \mathrm{wt} . \%$ and $0.5 \mathrm{wt} . \%$.

\section{Experimental Procedure}

Alloy 354 modified with $200 \mathrm{ppm}$ strontium and grain-refined using $0.25 \mathrm{wt} \% \mathrm{Ti}$ (added using Al-5\%Ti-1\%B master alloy) was used as the base alloy (coded alloy A). The chemical composition in wt. \% of the as-received 354 alloy ingots is listed in Table 1.

\subsection{Additions.}

(i) The addition of $\mathrm{Al}_{2} \mathrm{O}_{3}$ particles was carried out using a metal matrix composite (6061 alloy $+20 \mathrm{vol}$ $\% \mathrm{Al}_{2} \mathrm{O}_{3}$ ) having a 2-to-30 $\mu \mathrm{m}$ particle size.
TABle 1: Chemical composition of the as-received 354 alloy.

\begin{tabular}{lccccc}
\hline \multicolumn{7}{c}{ Element (wt \%) } \\
\hline $\mathrm{Si}$ & $\mathrm{Fe}$ & $\mathrm{Cu}$ & $\mathrm{Mn}$ & $\mathrm{Mg}$ & $\mathrm{Al}$ \\
9.1 & 0.12 & 1.8 & 0.0085 & 0.6 & 87.6 \\
\hline
\end{tabular}

(ii) The addition of $\mathrm{SiC}$ particles was done using a (359 alloy +20 vol \% SiC) metal matrix composite having a similar particle size.

(iii) Zirconium and nickel additions were made using $\mathrm{Al}-20 \mathrm{wt} \% \mathrm{Zr}$ and Al-20wt\% $\mathrm{Ni}$ master alloys, respectively.

Alloy A, with a chemical composition as shown in Table 1 , was melted in an electrical furnace at $780^{\circ} \mathrm{C}$, using a $60 \mathrm{~kg} \mathrm{SiC}$ crucible. The molten alloy was degassed using pure, dry argon injected into the melt for $20 \mathrm{~min}$ by means of a graphite impeller rotating at $135 \mathrm{rpm}$. Grain refining and modification of the melt were carried out using $\mathrm{Al}-5 \% \mathrm{Ti}-1 \%$ $\mathrm{B}$ and $\mathrm{Al}-10 \% \mathrm{Sr}$ master alloys, respectively, to obtain levels of $0.25 \mathrm{wt} . \% \mathrm{Ti}$ and $200 \mathrm{ppm} \mathrm{Sr}$ in the melt. Table 2 lists the chemical composition of the alloys which were investigated. The melt was poured into a preheated ASTM B-108 permanent mold (preheated to $460^{\circ} \mathrm{C}$ ), to prepare test bars; the dimensions of which are shown in Figure 1. Three samples for chemical analysis were also taken at the time of the casting; this was done at the beginning, in the middle, and at the end of the casting process to ascertain the exact chemical composition of each alloy.

As will be mentioned in a later subsection, heat treatment of the test bars used for tensile testing involved solution heat treating them at $495^{\circ} \mathrm{C}$ for 8 hours, followed by quenching in warm water at $60^{\circ} \mathrm{C}$, after which artificial aging was applied. In the present work, three aging temperatures $\left(155^{\circ}, 190^{\circ}\right.$, and $\left.350^{\circ} \mathrm{C}\right)$ and different aging times, up to $1000 \mathrm{~h}$ were used. After aging, the test bars were allowed to cool naturally at room temperature $\left(25^{\circ} \mathrm{C}\right)$. All heat treatments were carried out in an air-forced Lindberg Blue $\mathrm{M}$ electric resistance furnace. All of the samples, whether ascast, solution heat-treated, or aged, were tested to the point of fracture using an MTS servo-hydraulic mechanical testing machine at a strain rate of $4 \times 10^{-4} \mathrm{~s}^{-1}$.

Ten samples from each condition were tested, for a total of 80 conditions for each alloy. Three other conditions were tested for each alloy corresponding to $200 \mathrm{~h}, 600 \mathrm{~h}$, and $1000 \mathrm{~h}$ aging times, from which would be selected one specific aging temperature $\left(190^{\circ} \mathrm{C}\right)$; this will be explained in detail further on in the text. The values for the mechanical properties, namely, ultimate tensile strength (UTS), yield strength (YS), and percent elongation (\% $\mathrm{El})$, were gathered from the computerized system of the MTS machine.

Samples for metallography were sectioned from the tensile-tested bars of all the alloys studied, about $10 \mathrm{~mm}$ below the fracture surface; they were then individually mounted in Bakelite and subsequently polished to a fine finish using $1 \mu \mathrm{m}$ diamond suspension. The instrument used in this study was a Hitachi-SU-8000 FESEM, equipped with a standard secondary electron detector (SE), a backscatter electron detector (BSD), and an energy dispersive X-ray 
TABLE 2: Chemical composition of the 354 alloys used in this study (wt.\%).

\begin{tabular}{lccccccccccc}
\hline Alloy/Element & $\mathrm{Si}$ & $\mathrm{Fe}$ & $\mathrm{Cu}$ & $\mathrm{Mn}$ & $\mathrm{Mg}$ & $\mathrm{Ti}$ & $\mathrm{Sr}(\mathrm{ppm})$ & $\mathrm{Ni}$ & $\mathrm{Zr}$ & $\mathrm{Al}_{2} \mathrm{O}_{3}$ (volume\%) & $\mathrm{SiC}($ volume\%) \\
\hline $\mathrm{A} *$ & 9.43 & 0.08 & 1.85 & 0.01 & 0.49 & 0.22 & 150 & $\sim$ & $\sim$ & - & - \\
$\mathrm{B}$ & 9.43 & 0.08 & 1.85 & 0.01 & 0.49 & 0.21 & 165 & - & - & $\sim \mathbf{1 . 5}$ & - \\
$\mathrm{C}$ & 9.43 & 0.08 & 1.85 & 0.01 & 0.49 & 0.19 & 170 & - & - & - & - \\
$\mathrm{D}$ & 9.16 & 0.08 & 1.84 & 0.01 & 0.49 & 0.22 & 149 & $\mathbf{0 . 4 6}$ & $\sim$ & - \\
$\mathrm{E}$ & 9.10 & 0.07 & 1.83 & 0.00 & 0.49 & 0.21 & 145 & $\sim$ & $\mathbf{0 . 3 9}$ & - \\
$\mathrm{F}$ & 9.10 & 0.08 & 1.86 & 0.00 & 0.46 & 0.22 & 132 & $\mathbf{0 . 4 0}$ & $\mathbf{0 . 3 9}$ & - & - \\
$\mathrm{G}$ & 9.01 & 0.08 & 1.85 & 0.00 & 0.45 & 0.21 & 137 & $\mathbf{0 . 2 1}$ & $\mathbf{0 . 1 9}$ & - & - \\
\hline
\end{tabular}

* 354 base alloy; $\mathrm{Ni}, \mathrm{Zr}$, and dispersoid additions are highlighted in bold.

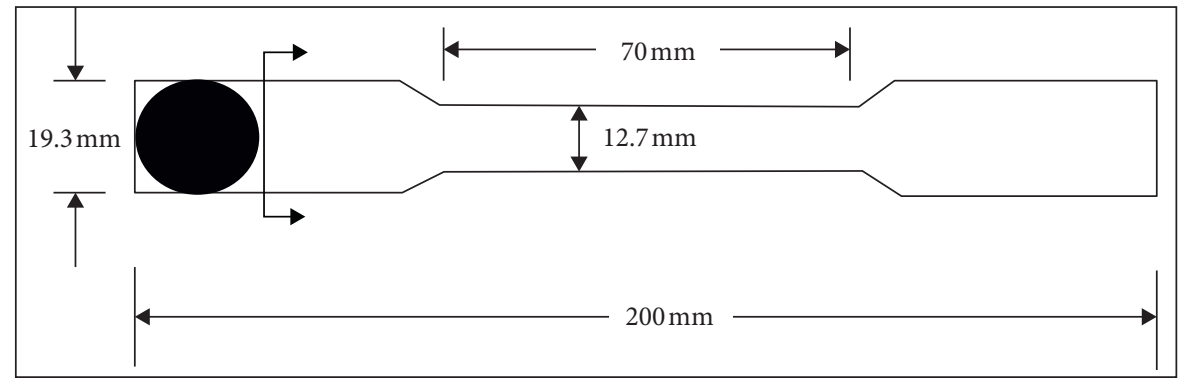

Figure 1: Dimensions of the tensile test bar.

spectrometer (EDS). The FESEM was operated at a voltage of $15 \mathrm{kV}$, with a maximum filament current of 3 amperes.

Transmission electron microscopy was used in order to observe and identify the strengthening precipitates in heattreated samples and also to investigate the coherency of the precipitates with the matrix. The FEI Tecnai $G^{2}$ F20 electron microscope employed was equipped with an advanced control system which permits the integration of an $\mathrm{EDAX}^{\mathrm{TM}}$ chemical analysis system, scanning transmission electron microscopy (STEM), and electron energy loss spectroscopy (EELS). The microscope was operated at an accelerating voltage of $200 \mathrm{kV}$.

\section{Results and Discussion}

In the present work, we are referring to the $\mathrm{Al}_{2} \mathrm{O}_{3}$ or $\mathrm{SiC}$ particulates as dispersoids in composites $\mathrm{B}$ and $\mathrm{C}$ containing these particulates since these particulates have no solubility in the matrix, maintaining at the same time uniform spacing. On the contrary, intermetallics are phases/compounds made up of two or more elements, producing a new phase with its own composition, crystal structure, and properties (Alloys $\mathrm{D}-\mathrm{G})$. Alloy $\mathrm{A}$ is the base alloy.

3.1. Microstructural Characterization. Figure 2(a) shows the microstructure of alloy $\mathrm{A}$ in the as-cast condition, revealing almost no presence of porosity. The blue arrows point to the change in the morphology of dendrites from elongated ones to a more rounded (rosetta-like) form which enhances feeding of the interdendritic regions, reducing the porosity in the grain-refined alloy as clearly displayed in Figure 2(b), a high-magnification micrograph of Figure 2(a). According to Campbell and Tiryakioglu [29], based on the work of Fuoco et al. [30], at an early stage of solidification, the dendrites can move as a slurry. Later, when eutectic freezing starts, the dendrites are fully solidified and fixed (about $45 \%$ remaining liquid) so that significant mobility of the eutectic is to be expected. However, after adding Sr, no mobility of the residual liquid is observed even at the high level of $45 \%$. This explanation, in addition to the change in the dendrite shape presented in Figure 2(b), contradicts the model presented by Argo and Gruzleski [31] which suggests that, in unmodified alloys, the eutectic is characterized by its irregular solid/ liquid interface, leading to entrapping of small pockets of liquid between advancing solidification fronts, causing the formation of microporosity. Figures 2(c) and 2(d), respectively, exhibit the distribution of the added $\mathrm{Al}_{2} \mathrm{O}_{3}$ and $\mathrm{SiC}$ particulates throughout the matrix, following solutionizing at $495^{\circ} \mathrm{C}$ for $8 \mathrm{~h}(\mathrm{SHT})$ revealing the complete dissolution of the $\mathrm{Al}_{2} \mathrm{Cu}$ phase. Figures 3 and 4 reveal the adherence (no debonding) between the particulates and the surrounding matrix.

In alloy $\mathrm{D}$, as the $\mathrm{Al}_{3} \mathrm{Zr}$ precipitate must be present before the peritectic reaction, the formation of $\mathrm{Al}_{3} \mathrm{Zr}$ from liquid is called a properitectic reaction $[32,33]$. In the present work, the $\mathrm{Zr}$ concentration used was $0.2 \mathrm{wt} . \%$ and 0.4 wt.\% for alloy G and alloys E-F, respectively. From Figure 5(a), the liquidus temperature should be $718^{\circ} \mathrm{C}$ and $780^{\circ} \mathrm{C}$, respectively. The melt was maintained at $780^{\circ} \mathrm{C}$, to avoid reaching the softening point of the $\mathrm{SiC}$ crucible. Thus, in the present case, $\mathrm{Zr}$-rich phases will be precipitated in the form of intermetallics as well as dispersoids (alloys E and F), whereas in the case of alloy $\mathrm{G}$, most of the $\mathrm{Zr}$ will be precipitated in the form of $\mathrm{Al}_{3} \mathrm{Zr}$ dispersoids.

It should be borne in mind that the present alloys contain at least 15 elements and that the solidification rate was approximately $8^{\circ} \mathrm{C} / \mathrm{s}$. These two criteria make it difficult 


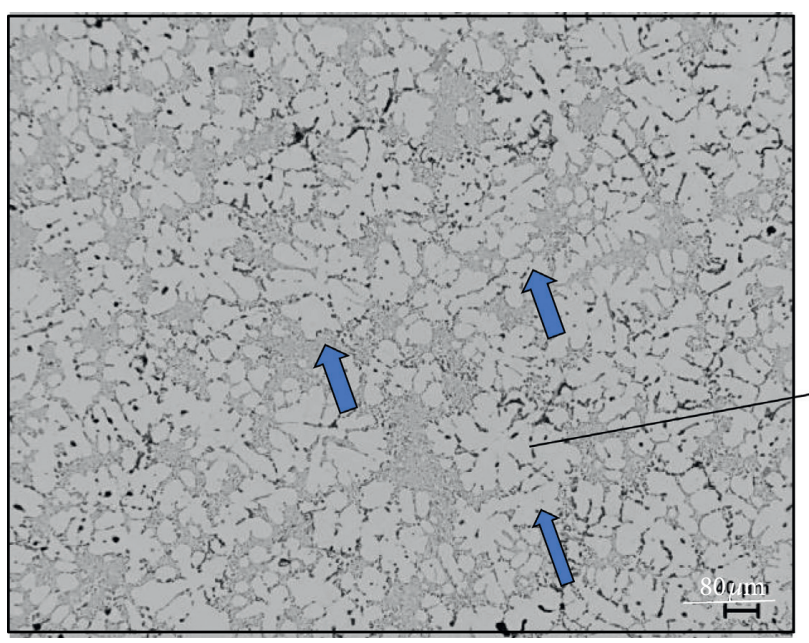

(a)

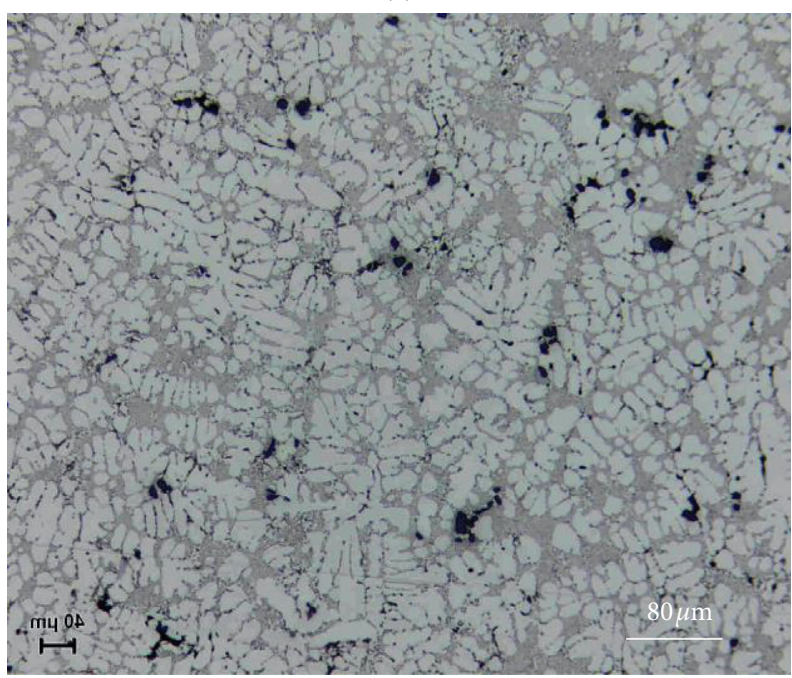

(c)

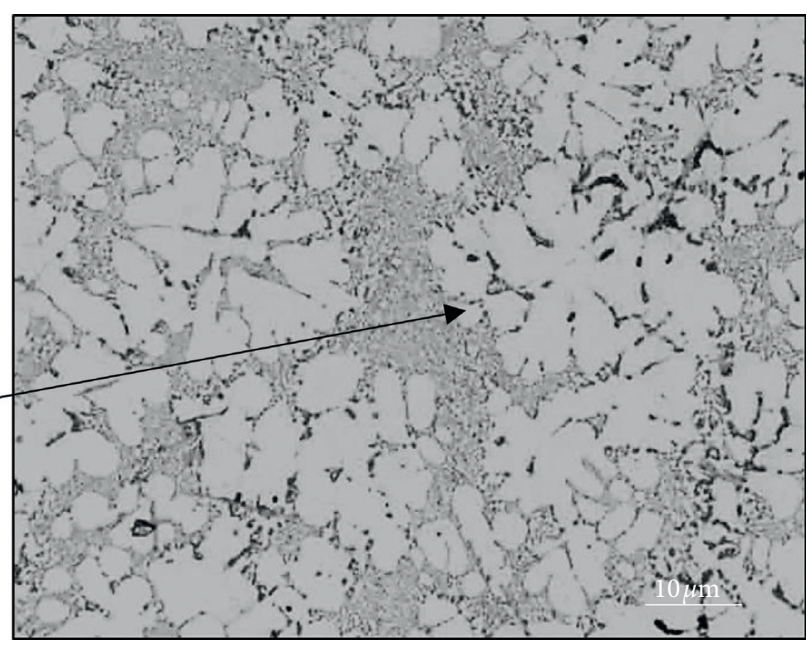

(b)

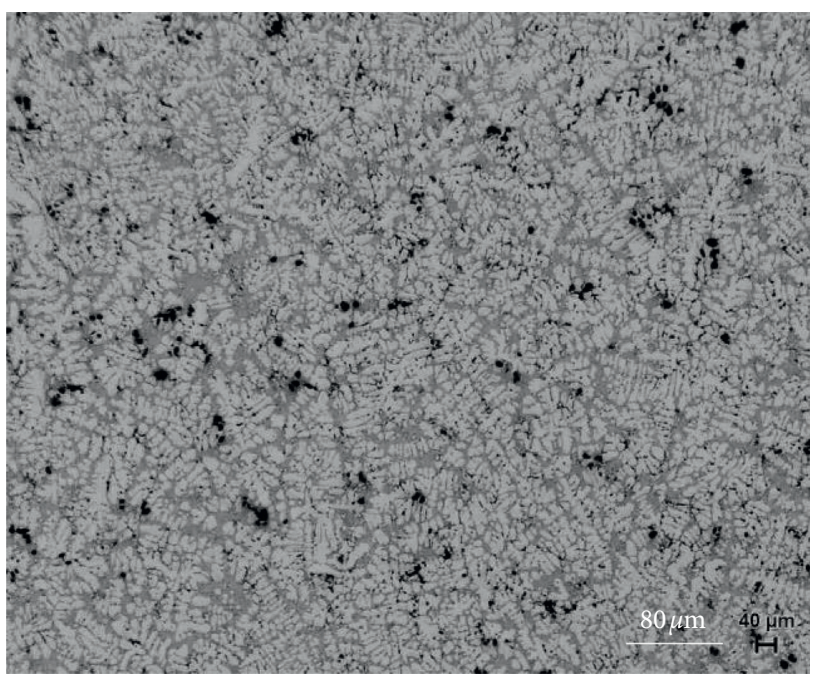

(d)

FIGURE 2: Optical microstructures of (a) alloy A, as cast, (b) a high-magnification micrograph of (a), (c) composite B-SHT, and (d) composite C-SHT.

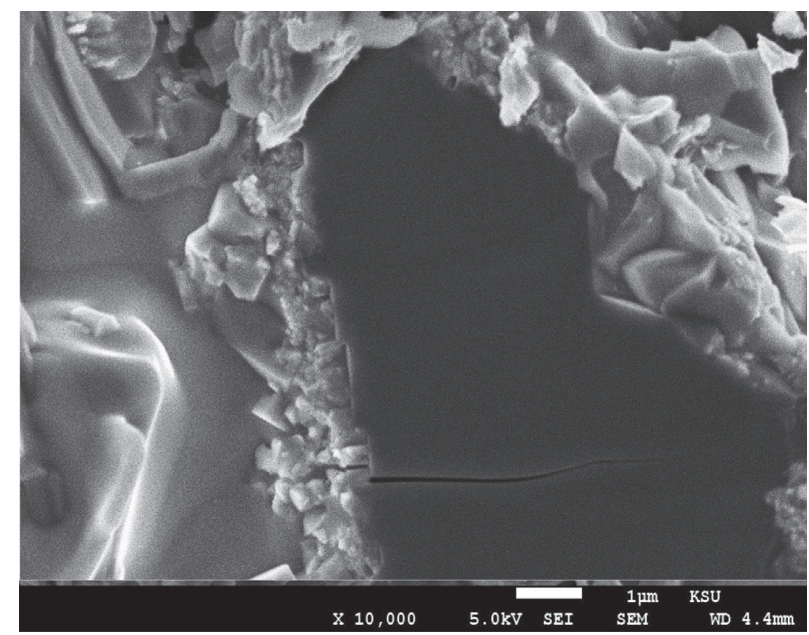

FIgURE 3: Secondary electron image of fracture surface of as-cast composite B. 


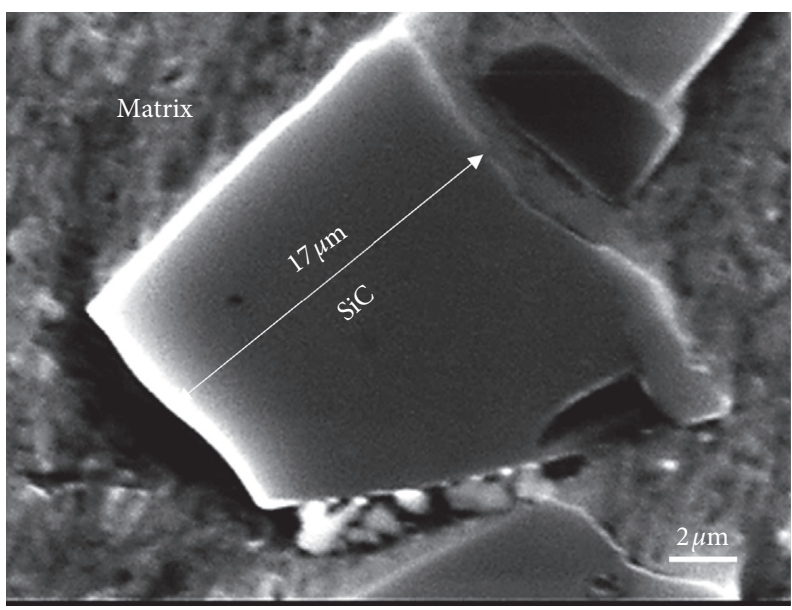

Figure 4: High-magnification secondary electron image of composite C. Note the absence of a gap between the SiC particle and the surrounding matrix.

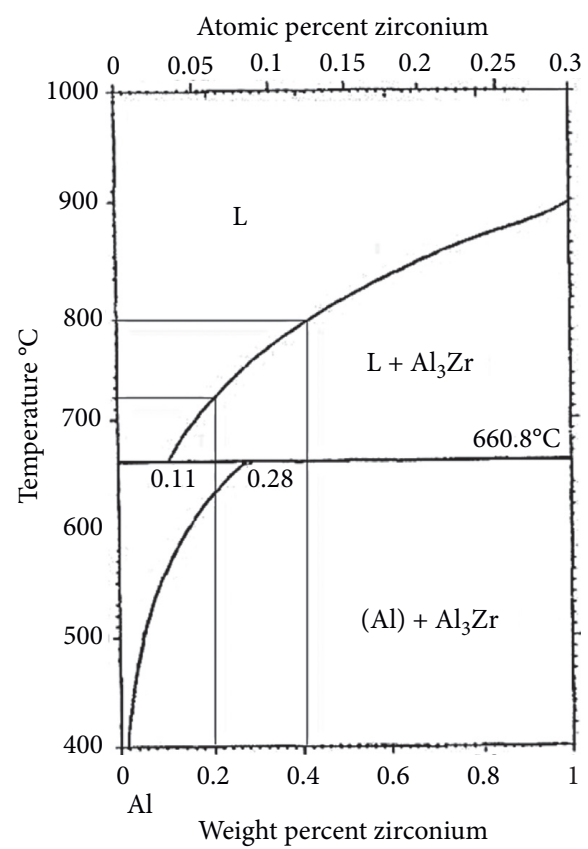

(a)

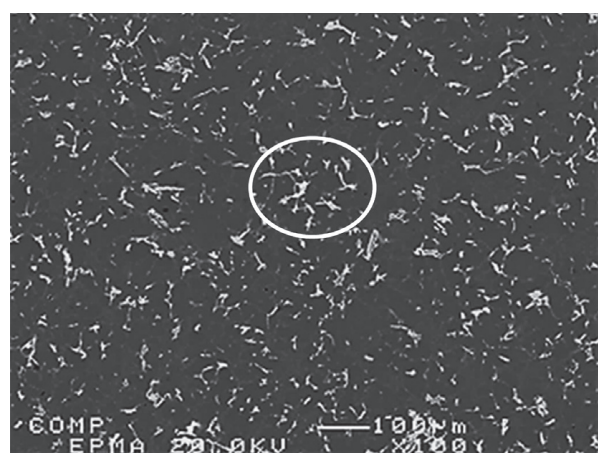

(b)

FIGURE 5: (a) Al-rich corner of Al-Zr binary phase diagram [33] showing the percentages of $\mathrm{Zr}$ used in the present study and (b) backscattered electron micrograph of alloy $\mathrm{D}$ solidified at the rate of $\sim 0.35^{\circ} \mathrm{C} / \mathrm{s}$.

to strictly follow the binary equilibrium diagram shown in Figure 5(a). Figure 5(b) depicts the Zr-rich phase distribution in alloy $\mathrm{D}$ in the as-cast condition, solidified at a very slow rate $\sim 0.35^{\circ} \mathrm{C} / \mathrm{s}$. In this case, the chemical composition of the dispersoid is $\mathrm{Al}-\mathrm{Zr}$-Ti as inferred from the associated EDS spectrum displayed in Figure 6(a). In the presence of Ti in the matrix, $\mathrm{Zr}$ has a strong affinity to react with Ti forming $\mathrm{Al}_{3}(\mathrm{Zr}, \mathrm{Ti})_{5}$ [34-36] or $\mathrm{Al}_{3}\left(\mathrm{Zr}_{1-x} \mathrm{Ti}_{x}\right)$ dispersoids [36]. Figure 7 depicts the precipitation of $\mathrm{Al}_{3} \mathrm{Zr}$ dispersoids in alloy $\mathrm{D}$ in the as-cast condition, in a sample prepared from a tensile test bar solidified at about $8^{\circ} \mathrm{C} / \mathrm{s}$. According to Ikhlaq et al. [34], Zr has a preferred orientation (002) along other significant diffraction planes (100), (101), (102), and (110) of $\mathrm{Zr}$ confirming the hexagonal crystal structure as shown in Figure 6(b).

Figure 8 displays the progress in the size and distribution of the $\mathrm{Al}_{2} \mathrm{Cu}$ precipitation hardening particles (main hardening agent) at $190^{\circ} \mathrm{C}$ (peak aging). It is evident from Figures $8(\mathrm{~b})$ and $8(\mathrm{c})$ that with increase in the aging time, there is an increase in the size of the precipitated $\mathrm{Al}_{2} \mathrm{Cu}$ particles coupled with change in their morphology from spherical to short rods, which leads to a gradual decrease in contribution of these precipitates to both UTS and YS regardless the alloy type, reaching almost nil after $1000 \mathrm{~h} \mathrm{[37].}$ 


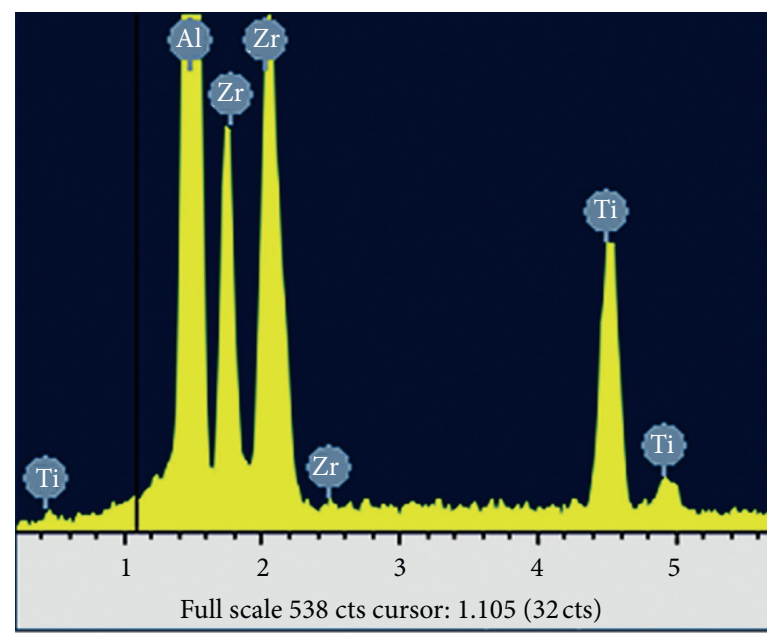

(a)

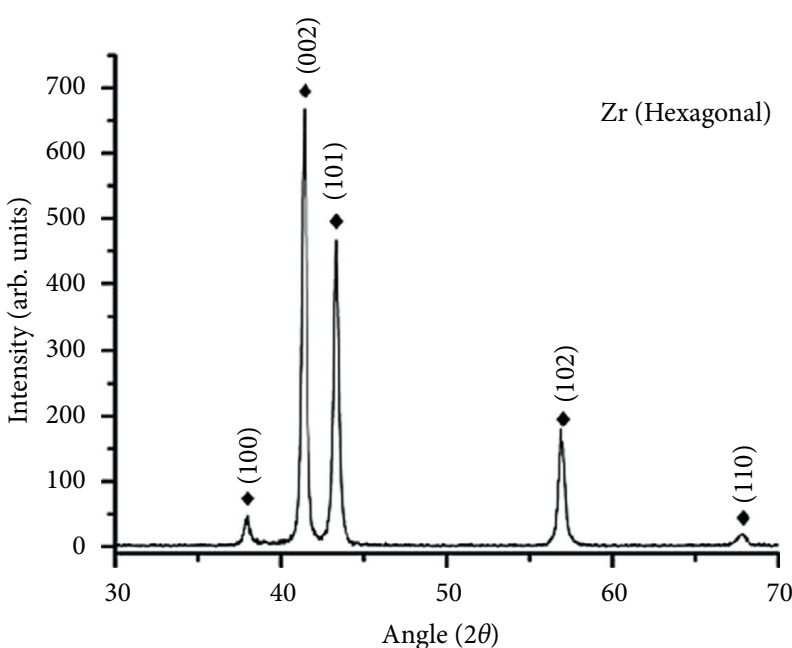

(b)

FIGURE 6: (a) EDS spectrum corresponding to white circled area in Figure 5(b) showing strong reflections from $\mathrm{Al}, \mathrm{Zr}$, and Ti and (b) X-Ray diffraction spectrum for zirconium metal [34].

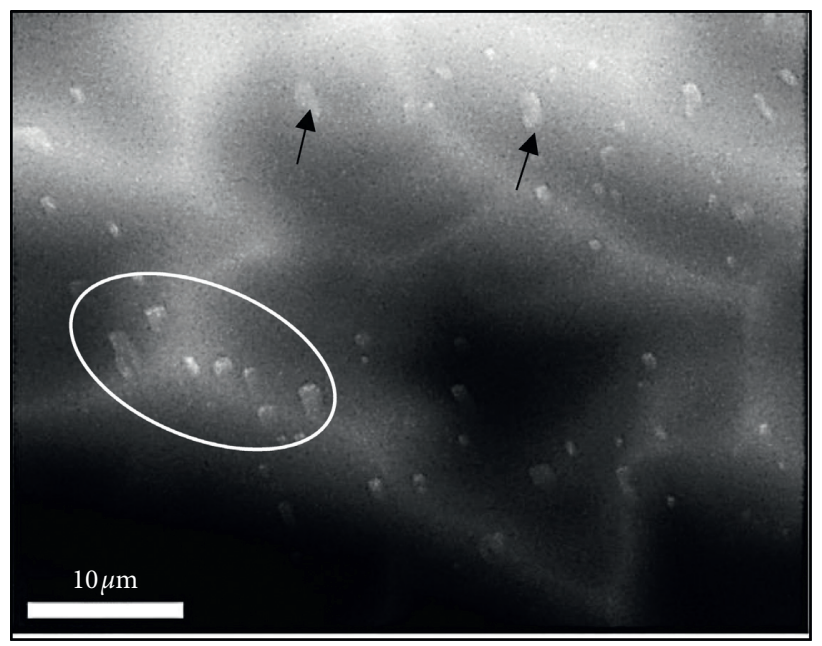

(a)

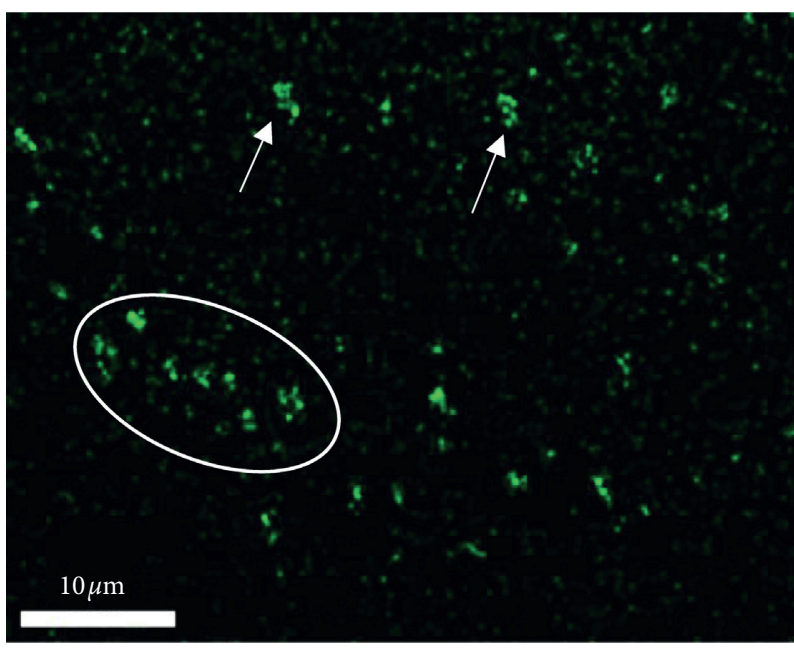

(b)

Figure 7: Continued. 


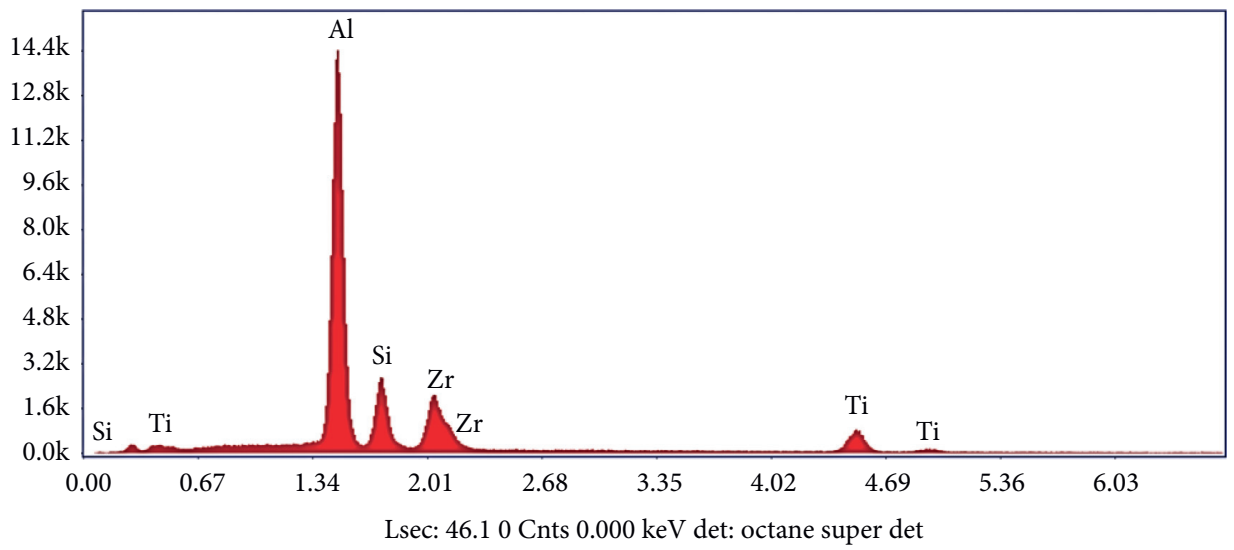

(c)

$\begin{array}{lccccccccc}\text { Element } & \begin{array}{c}\text { Weight } \\ \%\end{array} & \begin{array}{c}\text { Atomic } \\ \%\end{array} & \text { Net Int. } & \text { Error \% } & \text { Kratio } & \text { Z } & \text { R } & \text { A } & \text { F } \\ \text { AlK } & 48.15 & 63.08 & 2,523.32 & 3.35 & 0.48 & 1.09 & 0.96 & 0.9 & 1.01 \\ \text { SiK } & 11.16 & 14.05 & 457.67 & 5.50 & 0.10 & 1.11 & 0.97 & 0.76 & 1.01 \\ \text { ZrL } & 20.42 & 7.91 & 344.71 & 5.08 & 0.15 & 0.81 & 1.13 & 0.88 & 1.01 \\ \text { TiK } & 20.27 & 14.95 & 199.60 & 5.56 & 0.19 & 0.93 & 1.01 & 0.98 & 1.02\end{array}$

(d)

Figure 7: (a) Bright field electron micrograph of the precipitation of Al-Zr-Ti dispersoids in alloy D in the as-cast condition, (b) map of Zr distribution in (a), (c) EDS spectrum corresponding to white circle in (a), and (d) approximate composition of particles in (a). The average size of Zr-rich precipitates in (a) is about $20-30 \mathrm{~nm}$.

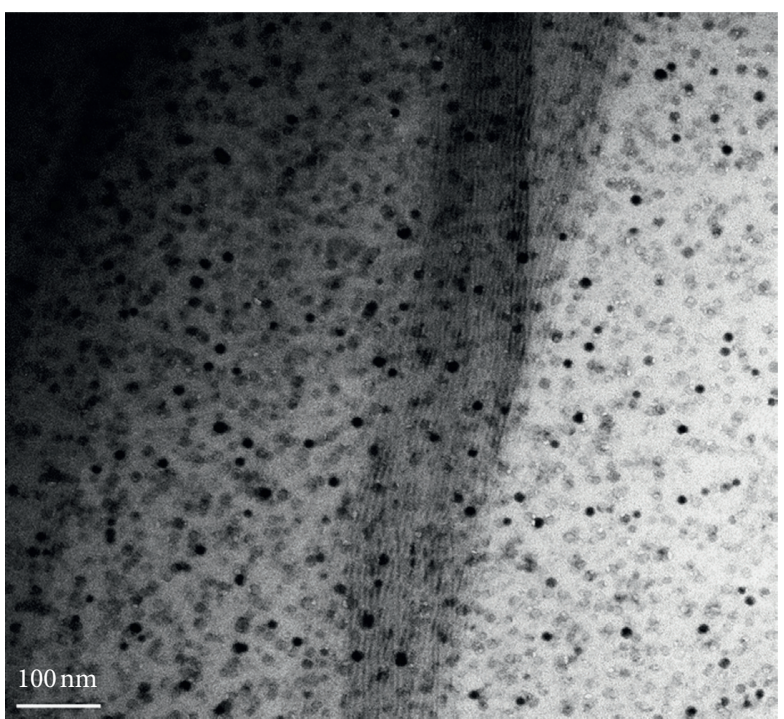

(a)

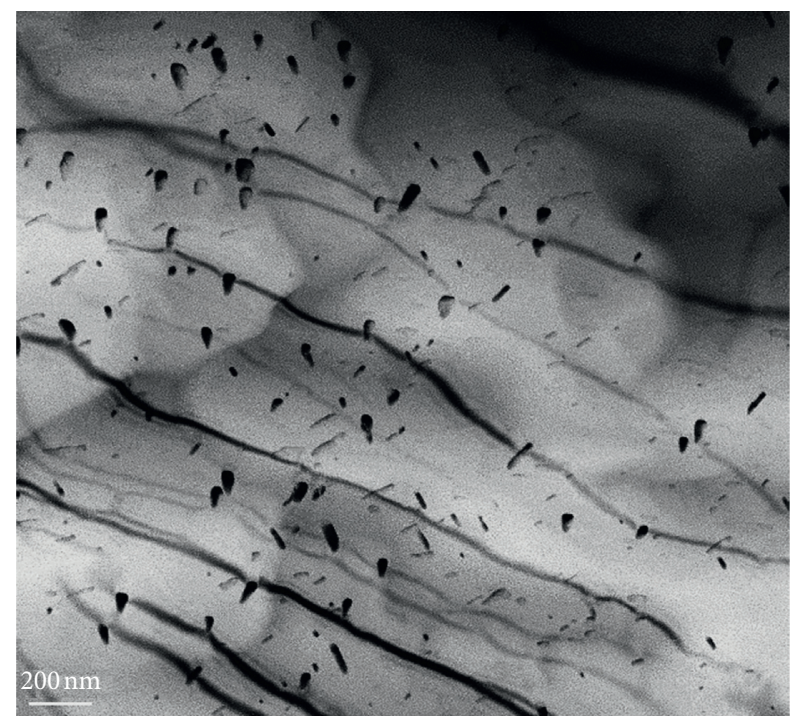

(b)

Figure 8: Continued. 


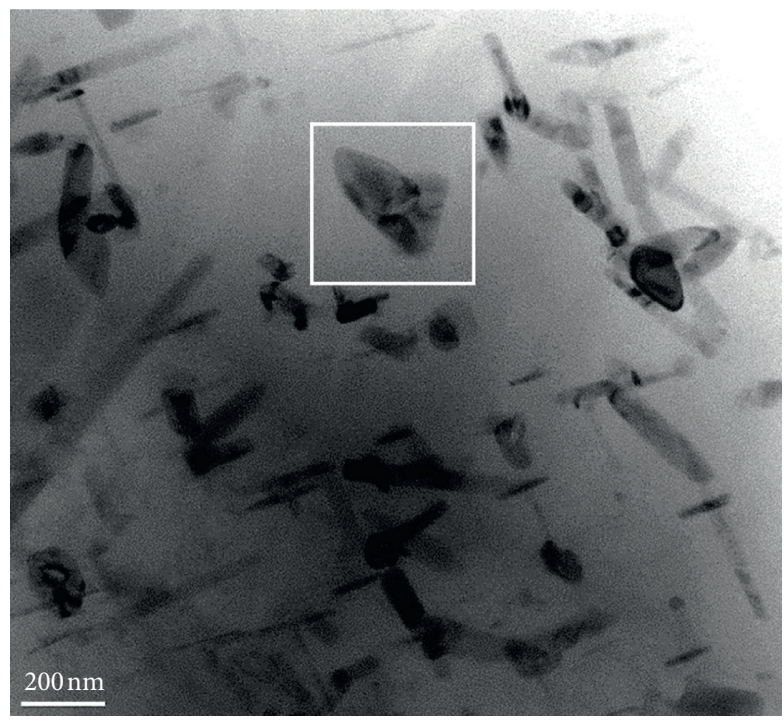

(c)

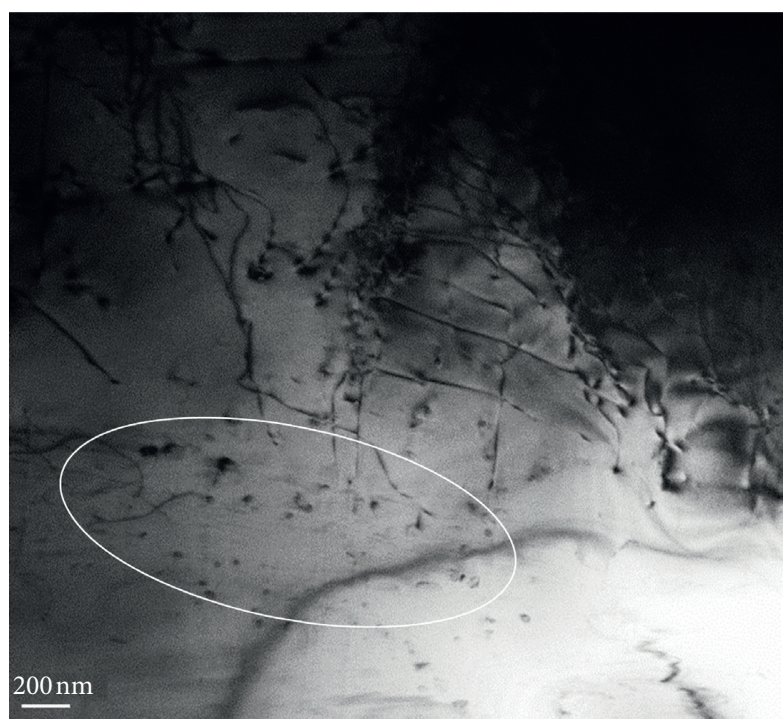

(e)

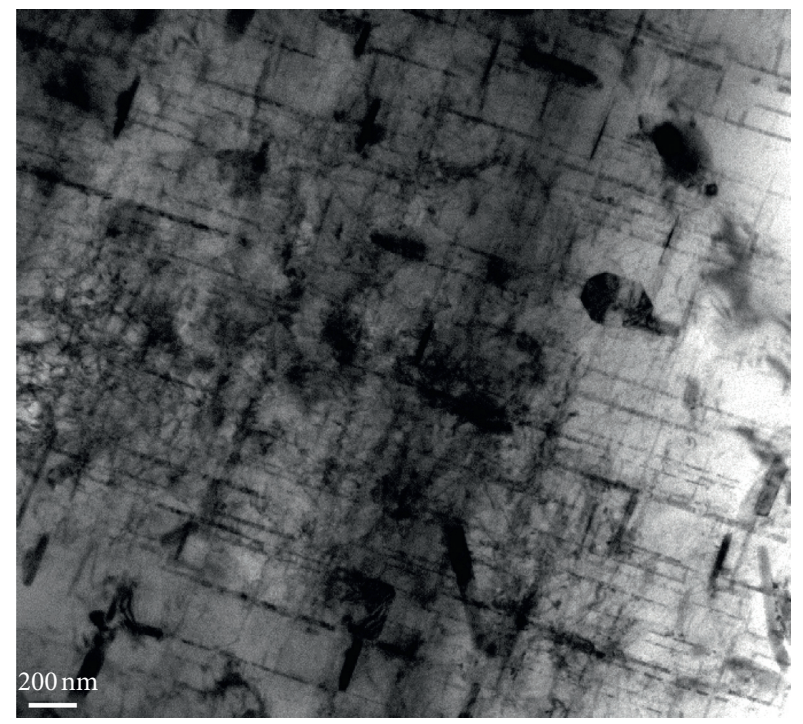

(d)

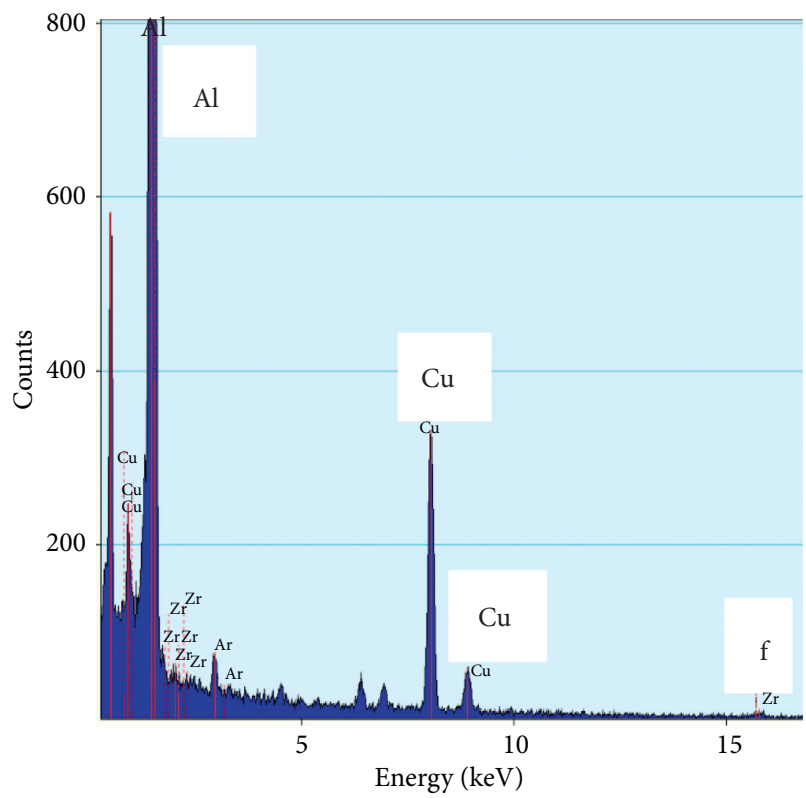

(f)

FIGURE 8: Bright field electron micrographs showing the progress in the size and distribution of the precipitated second phase during aging at 190 o C. (a) $2 \mathrm{~h}$, (b) $200 \mathrm{~h}$, (c) $1000 \mathrm{~h}$, (d) dislocation/particle imteractions in condition (c), note the high dislocation density, (e) dislocation density in alloy A after solutionizing treatment, note the size of the preciptated particles in the white area, and (f) EDS spectrum corresponding to square area in (c) revealing $\mathrm{Al}$ and $\mathrm{Cu}$ peaks.

Figure 8(d) shows dislocation/precipitate interactions; note the significant increase in the dislocation density compared to that after solutionizing treatment (Figure 8(e)). Figure 8(f) presents the EDS spectrum, corresponding to the white square area in Figure 8(c), indicating reflections due to $\mathrm{Al}$ and $\mathrm{Cu}$.

3.2. Tensile Properties. Table 3 lists the tensile parameters of alloy $\mathrm{A}$ in the as-cast condition. Figure 9 presents the contribution of added particulates or alloying elements on the tensile properties of the 354 alloys B through G, using
TABle 3: Tensile properties of alloy $\mathrm{A}$ in the as-cast condition.

\begin{tabular}{lccc}
\hline Parameter- & UTS $(\mathrm{MPa})$ & YS $(\mathrm{MPa})$ & $\% \mathrm{El}$ \\
\hline Value & 235 & 154 & 1.6 \\
\hline
\end{tabular}

alloy $\mathrm{A}$ in the as-cast condition as a reference point. It should be mentioned here that, in a previous study, the authors reported on the aging behavior of alloy $\mathrm{A}$ in the temperature rage $155^{\circ} \mathrm{C}-350^{\circ} \mathrm{C}$ for times up to $100 \mathrm{~h}$ [38].

As can be seen in Figure 9(a), when the alloys were aged at $155^{\circ} \mathrm{C}$ for $2 \mathrm{~h}$, composite B (containing maximum $1.5 \mathrm{vol} \%$ 


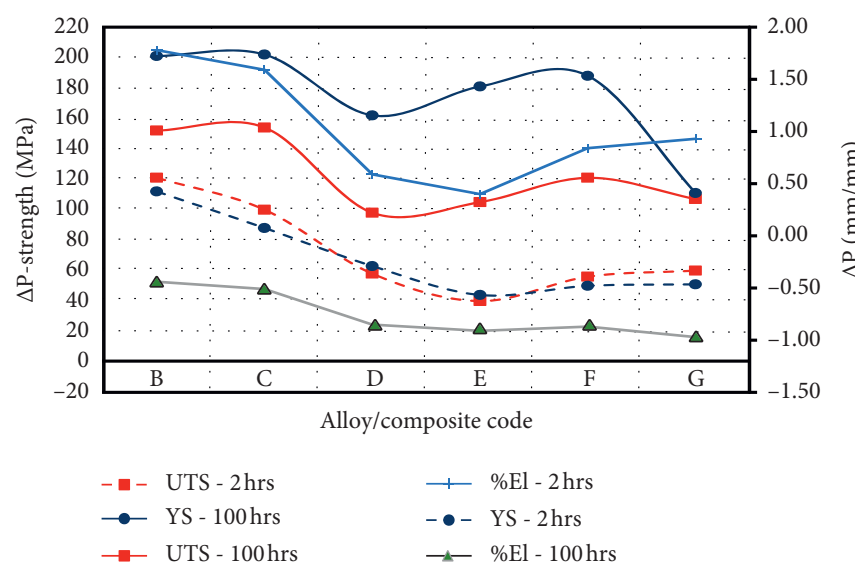

(a)

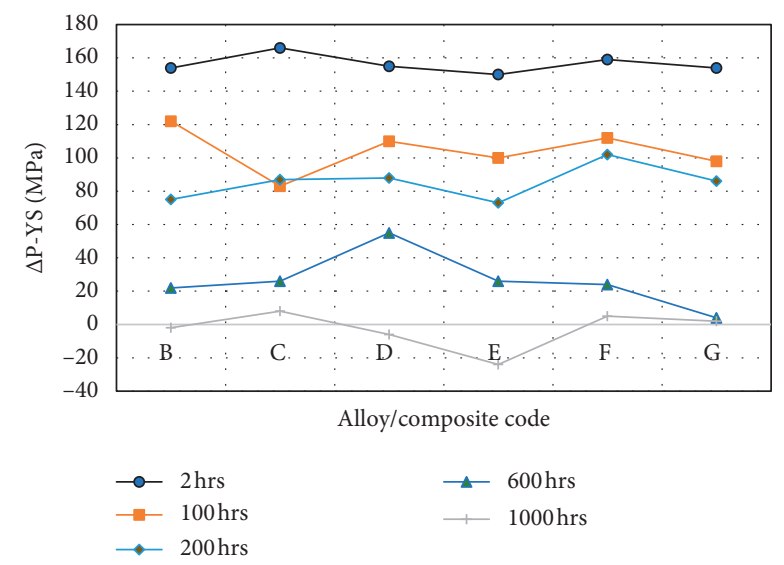

(c)

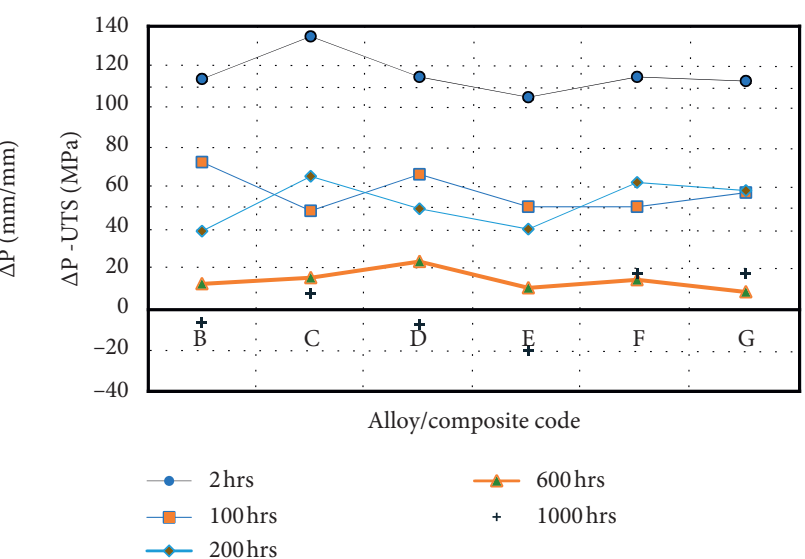

(b)

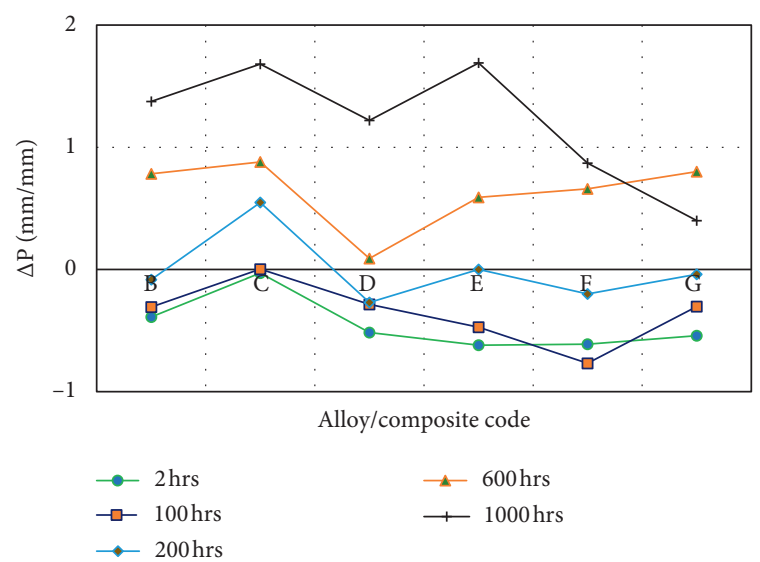

(d)

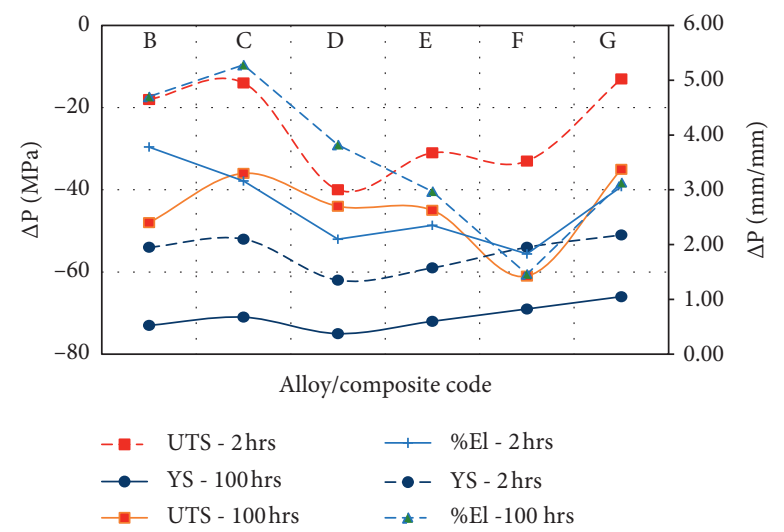

(e)

Figure 9: Variation in $\Delta \mathrm{P}$ as a function of aging condition: (a) $155^{\circ} \mathrm{C}$, (b) UTS- $190^{\circ} \mathrm{C}$, (c) $\mathrm{YS}-190^{\circ} \mathrm{C}$, (d) $\%$ El-190 ${ }^{\circ} \mathrm{C}$, and (e) $350^{\circ} \mathrm{C}$.

$\mathrm{Al}_{2} \mathrm{O}_{3}$ ) contributed significantly to the UTS of alloy A (about $120 \mathrm{MPa})$ followed by a linear decrease up to alloy $\mathrm{E}$ (40 MPa) beyond which other alloys (alloys F and $\mathrm{G}$ ) showed a slight increase in UTS, going to 56 and $60 \mathrm{MPa}$, respectively. Aluminum oxide particulates are a ceramic compound with a hexagonal crystal lattice. The oxygen anions define a hexagonal close packed structure, and the aluminum cations occupy $2 / 3$ of the octahedral sites in the hcp lattice. It is used for its hardness and strength, about 9 on the Mohs scale of mineral hardness (just below diamond) [34].
Although $\mathrm{SiC}$ (composed of tetrahedra of carbon and silicon atoms with strong bonds in the crystal lattice) is a very hard and strong material [39], its contribution is slightly lesser than that of $\mathrm{Al}_{2} \mathrm{O}_{3}$ which may be interpreted in terms of the actual particulate volume fraction. However, both composites $\mathrm{B}$ and $\mathrm{C}$ offered a better resistance to softening, yield strength, as well as a better improvement in the alloy ductility compared to those obtained from the other alloys containing Ni or Zr. Figures 9(b) to 9(d) demonstrate the variation in the UTS, YS, and \% elongation, respectively, 
when both particulates and alloying elements were added to alloy $\mathrm{A}$. The tensile bars were exposed to aging at $190^{\circ} \mathrm{C}$ for times up to $1000 \mathrm{~h}$.

A comparison of Figures 9(b) and 9(c) shows that the contribution level to the alloy YS is higher than that to the UTS. Although the contribution to the ductility of alloy A in Figure 9(d) followed a similar pattern as those for UTS and YS, a sharp decrease in the \%El was observed for alloys $\mathrm{F}$ and $\mathrm{G}(1000 \mathrm{~h})$. On the contrary, low aging times $(2 \mathrm{~h}-100 \mathrm{~h})$ resulted in a negative change in the \% elongation. Some improvement can be seen for alloy $\mathrm{G}$ that contains $0.25 \%$ $\mathrm{Zr}+0.25 \% \mathrm{Ni}$ producing same levels as composites $\mathrm{B}$ and $\mathrm{C}$ due to precipitation of $\mathrm{Al}_{3} \mathrm{Zr}$ dispersoids.

Daoud and Reif [40] suggested that the hardening process is significantly affected by the presence of microoxides, carbides, or SiC. The precipitation takes place on the dislocation lines. As a result of the mismatch between the coefficient of thermal expansion of the matrix and the reinforcement, it is not expected to alter the precipitation sequence. Samuel et al. [41] proposed that the relative amount of hardening precipitates is also influenced by the added dispersoids. In order to achieve a significant improvement in the alloy strength, the authors recommended increasing the reinforcement particulates by an order of magnitude than those used in composites $\mathrm{B}$ and C. Apparently, the added amounts of $\mathrm{Al}_{2} \mathrm{O}_{3}$ or $\mathrm{SiC}$ in the present study have a marginal effect on the composite tensile properties compared to $\mathrm{Zr}$ and $\mathrm{Ni}$ addition.

As will be observed from Figure 10, the highest standard deviations with respect to UTS are exhibited by the alloys containing micro-oxides; also, the variations are more accentuated for the temperatures where the maximum strength values were observed, i.e., at $155^{\circ} \mathrm{C}$ and $190^{\circ} \mathrm{C}$. This figure is showing the average standard deviation values for all alloys studied, where the higher standard deviation values may be observed for the properties pertaining to composites $\mathrm{B}$ and C. In Figure 11, the maximum standard deviations correspond to the maximum ductility values, observed at $155^{\circ} \mathrm{C}$ and $350^{\circ} \mathrm{C}$ for alloys containing micro-oxides/carbides. In both Figures 10 and 11, the tensile test values corresponding to these two temperatures reveal the highest standard deviations, particularly for composites B and C, when the seven alloys used in this study are subjected to comparison.

3.3. Fracture Behavior. Figure 12(a) represents the fracture surface of alloy $\mathrm{A}$ in the as-cast condition (secondary electron image) where severe cracks (arrowed blue) can be seen propagating through the fine-dimpled structure $(1.3 \%$ elongation). Solutionizing at $495^{\circ} \mathrm{C}$ for $8 \mathrm{~h}$ resulted in a significant increase in the alloy ductility (6.3\%) which reflected on the alloy surface fracture as displayed in Figure 12(b) where a deep dimple structure is seen predominating the fracture surface-blue arrows. Slip bands are observed covering the wall of the dimples shown in Figure 12(b). Figure 12(c) exhibits the fracture surface of alloy A aged at $190^{\circ} \mathrm{C}$ for $2 \mathrm{~h}$ revealing severe cracks (white arrows), whereas similar features as those shown in

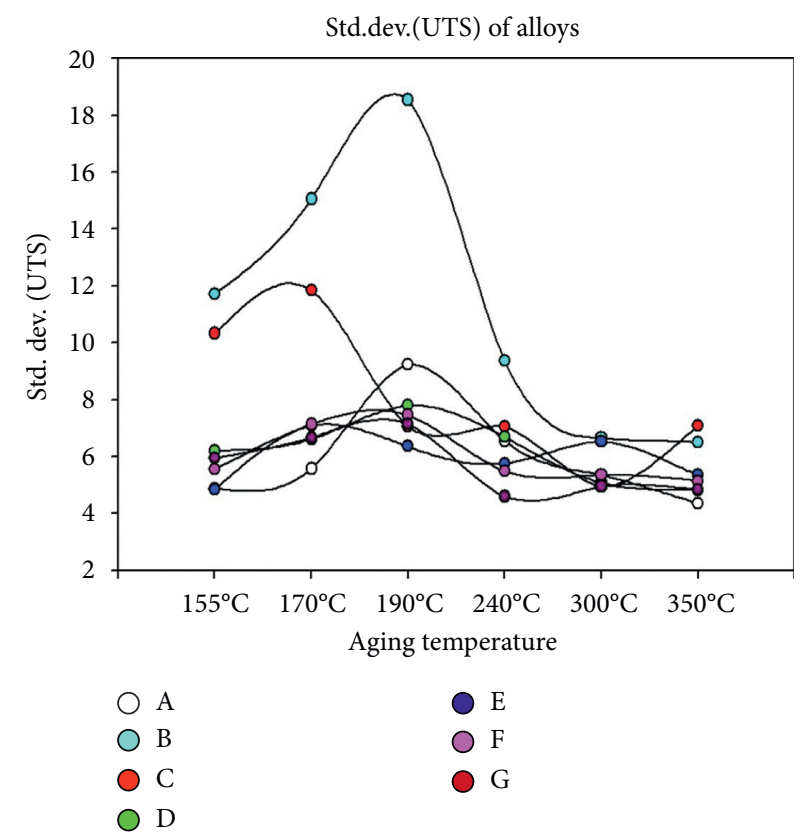

FIgURE 10: Mean standard deviation of the UTS values observed for the five alloys and two composites studied.

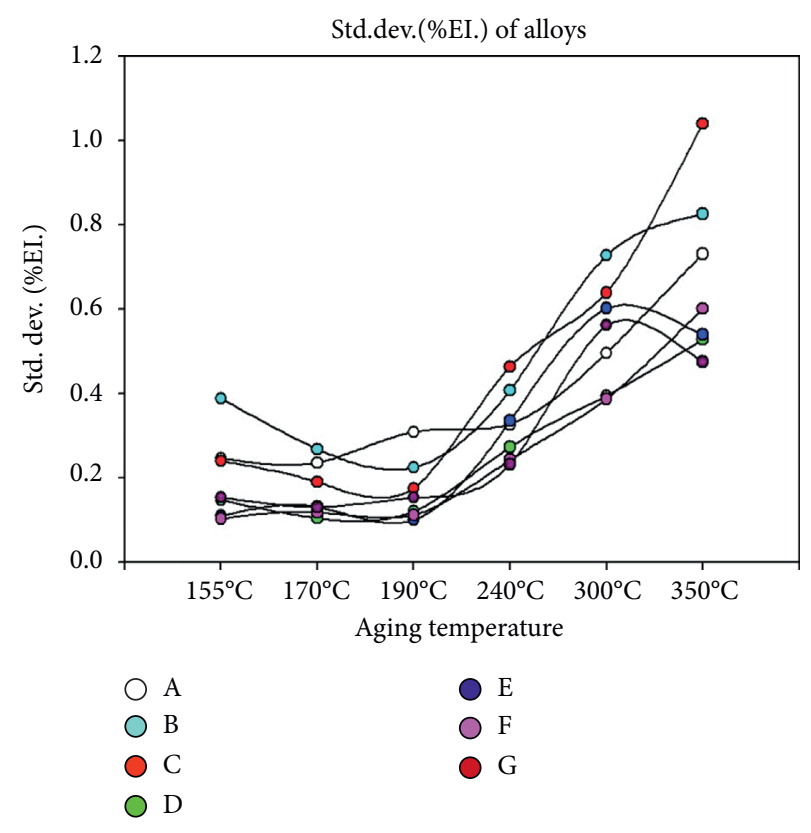

Figure 11: Mean standard deviation of the \% elongation values observed for the five alloys and two composites studied.

Figure 12(b) were reported covering the fracture surface when the alloy was aged at $350^{\circ} \mathrm{C}$ for $100 \mathrm{~h}$ (overaging), see arrows in Figure 12(d). In composite C, Figure 13, the presence of micro-SiC particulates were seen at the bottom of the coarse dimples (white arrows) when the alloy was solutionized (reaching 5.3\% ductility). In all solutionized alloys, clear slip bands were commonly observed as shown by the blue arrows in the figure. The fracture surface of alloy $\mathrm{D}$ (containing $0.4 \% \mathrm{Zr}$ ) after solutionizing treatment resulted 


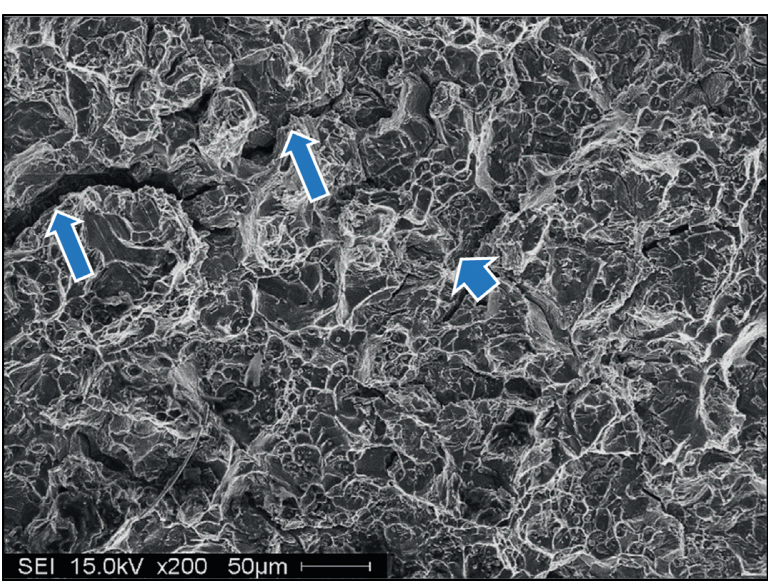

(a)

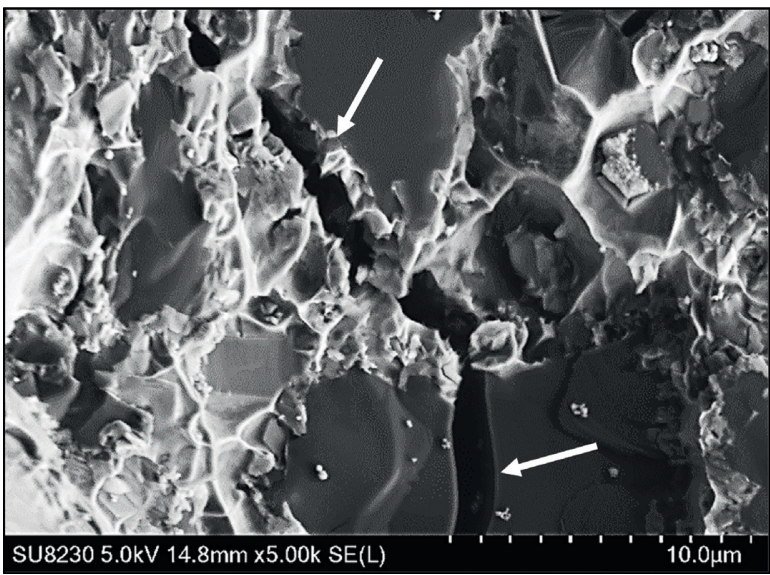

(c)

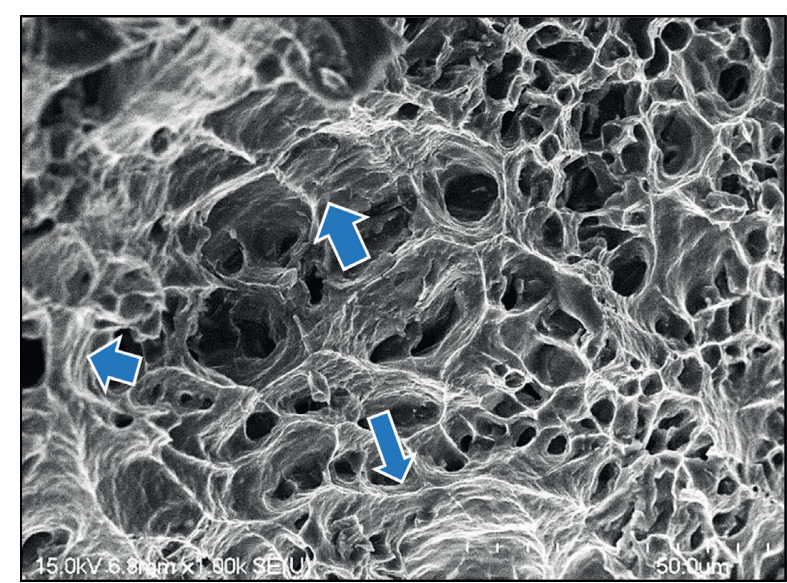

(b)

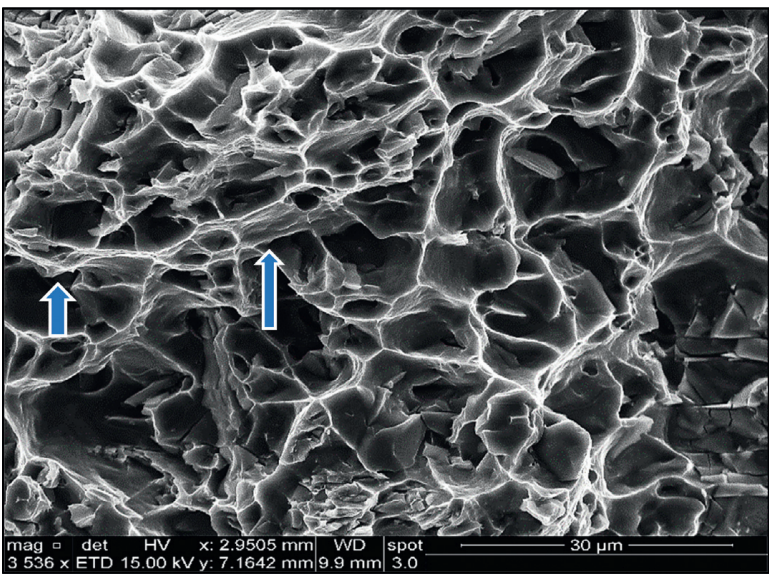

(d)

FIGURE 12: Secondary electron images (SEI) of the fracture surface of alloy (A). (a) as-cast condition (1.3\% El), (b) SHT condition (6.2\% El), (c) alloy $\mathrm{A}$ aged $2 \mathrm{~h}$ at $190^{\circ} \mathrm{C}(1.7 \% \mathrm{El})$, and (d) alloy $\mathrm{A}$ aged $100 \mathrm{~h}$ at $350^{\circ} \mathrm{C}(5.8 \% \mathrm{El})$.

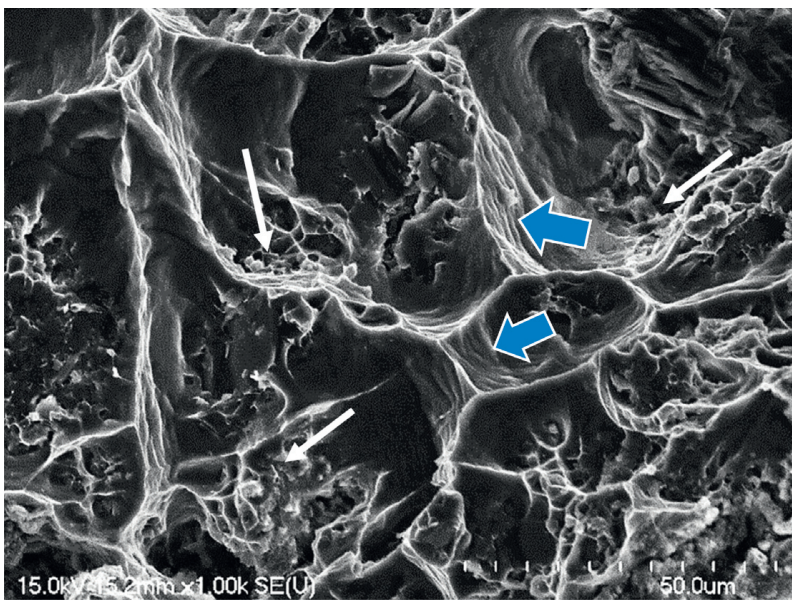

FIGURE 13: SEI of the fracture surface of composite C in the SHT condition (5.3\%El).

in enhancing the alloy ductility, reaching about $4.5 \%$. While the SHT did not change the shape of the star-like particles, Figure 14(a) shows several slip lines clearly visible on the edges (black arrows) of the particle, as well as a long crack reaching the star center (white dashed arrow). The associated
EDS spectrum, Figure 14(b), exhibits reflections due to Al, $\mathrm{Si}, \mathrm{Zr}$, and Ti elements suggesting that the composition of this phase is $(\mathrm{Al}, \mathrm{Si})_{2}(\mathrm{Ti}, \mathrm{Zr})$ [28].

Figure 15(a) demonstrates the fracture of alloy $\mathrm{E}$ in the as-cast condition. It is evident that the presence of such a 


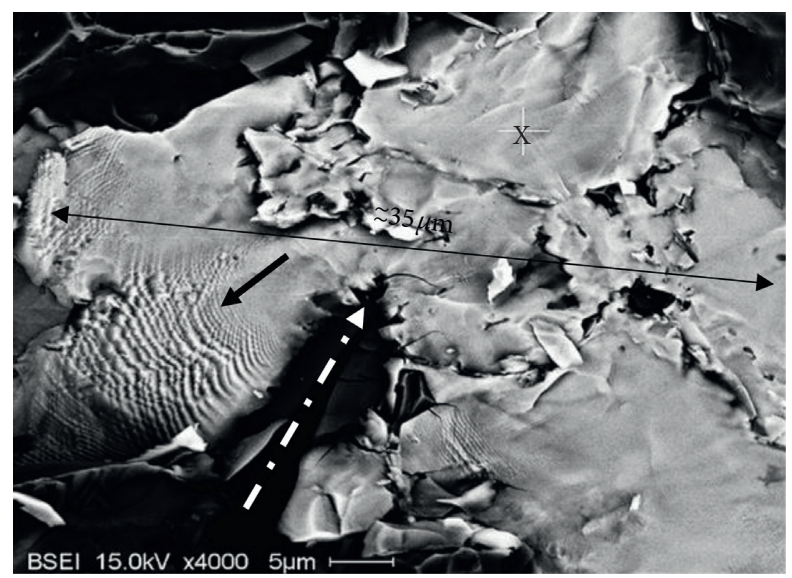

(a)

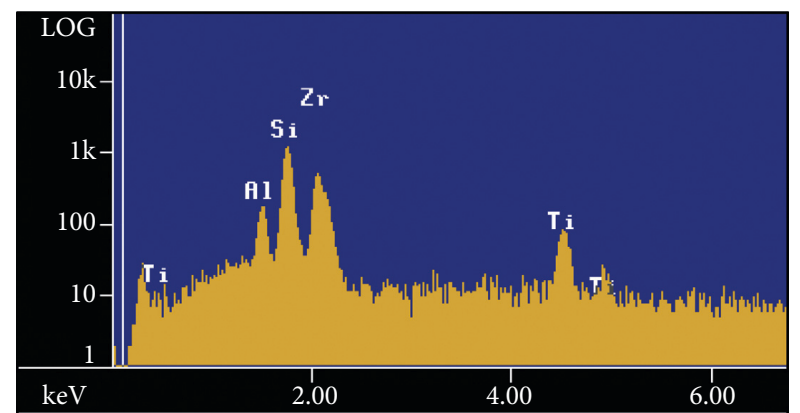

(b)

FIGURE 14: (a) Backscattered electron micrograph of alloy D after solutionizing treatment (4.5\%El) and (b) EDS spectrum corresponding to the area marked $\mathrm{X}$ in $(\mathrm{a}),(\mathrm{Al}, \mathrm{Si})_{2}(\mathrm{Zr}, \mathrm{Ti})$ phase.

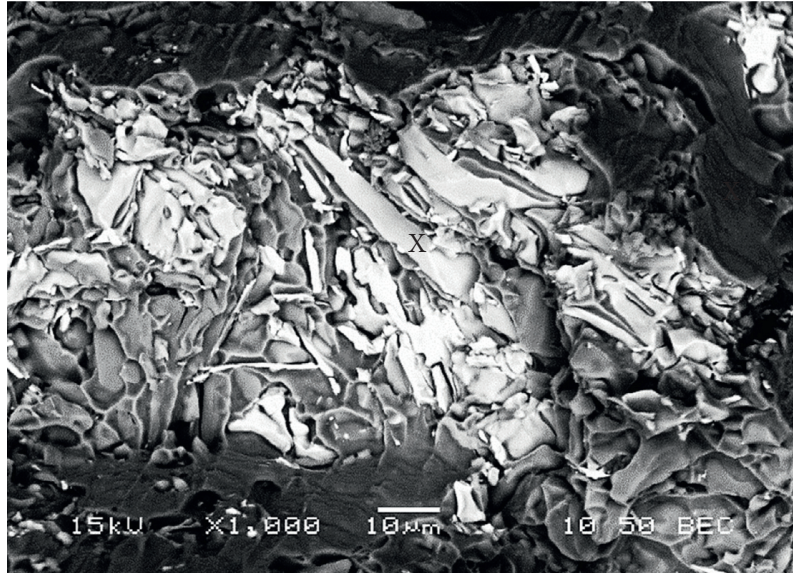

(a)

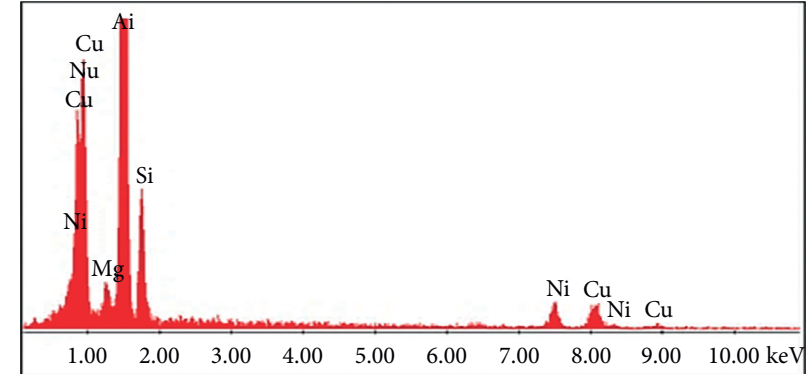

(b)

FIGURE 15: (a) SEI of fractured Ni-rich phase-alloy E $(1.44 \% \mathrm{El})$ in the as-cast condition, note the platelet shape of the Ni-rich compounds and (b) EDS spectrum corresponding to (a).

significant amount of insoluble Ni-rich phases would cause marked brittleness (1.44\%El). The associated EDS spectrum in Figure 15(b), corresponding to the marked spot in (a), shows strong peaks of $\mathrm{Al}, \mathrm{Ni}, \mathrm{Cu}$, and $\mathrm{Si}$ with a small peak of $\mathrm{Mg}$ indicating a mixture of $\mathrm{Al}_{3} \mathrm{CuNi}$ and $\mathrm{Q}-\mathrm{Al}_{5} \mathrm{Cu}_{2} \mathrm{Mg}_{8} \mathrm{Si}_{6}$ phases. The fracture surface of alloy $\mathrm{F}$ (containing about $0.4 \% \mathrm{Ni}+0.45 \mathrm{Zr}$ ) is illustrated in Figure 16(a) showing a fractured massive $\mathrm{Zr}$-rich phase particle. The black arrow points to parallel markings on the surface of the particle. The associated EDS spectrum corresponding to the area marked $\mathrm{X}$ in (a) reveals that this phase is possibly $(\mathrm{Al}, \mathrm{Si})_{3}(\mathrm{Ti}, \mathrm{Zr})$, depending on the $\mathrm{Si} / \mathrm{Zr}$ intensity ratio [42].

Based on the EDS spectra presented in Figures 7(c), 14 (b), and 16(b), the Si/Zr intensity ratios are $0,0.5$, and 1 , respectively, depending on the $\mathrm{Zr}$-rich phase particle size. According to Garza-Elizondo et al. [43], the ( $\mathrm{Al}, \mathrm{Si})_{2}(\mathrm{Ti}, \mathrm{Zr})$ phase contains $36 \mathrm{wt} . \% \mathrm{Si}$ and $38 \mathrm{wt} . \% \mathrm{Zr}$, whereas the $(\mathrm{Al}, \mathrm{Si})_{3}(\mathrm{Ti}, \mathrm{Zr})$ phase contains 11 wt.\% $\mathrm{Si}$ and 47 wt.\% $\mathrm{Zr}$, reaching $\mathrm{Al}_{3} \mathrm{Zr}$ when $\mathrm{Si}$ is practically nil. The atomic radii of $\mathrm{Al}, \mathrm{Si}, \mathrm{Ti}$, and $\mathrm{Zr}$ are listed in Table 4 . The $\mathrm{Al}_{3} \mathrm{Zr}$ phase is a closed packed structure (Figure 17(a)) with an interatomic spacing of $0.441 \mathrm{~nm}$. However, there is controversy regarding the particle structure which has been reported as being cubic $\mathrm{Ll}_{2}$ or tetragonal DO23, as shown in Figure 17(b) $[42,43]$. It is also reported that $\mathrm{Al}_{3} \mathrm{Zr}$ has the stable DO23 structure, but for small supersaturations of the solid solution, $\mathrm{Al}_{3} \mathrm{Zr}$ precipitates with the metastable $\mathrm{Ll}_{2}$ structure and precipitates with the DO23 structure only appear for prolonged heat treatment and high enough supersaturations $[44,45]$.

It is suggested that since the $\mathrm{Si}$ atom has a small radius (Table 4) compared to the interatomic spacing in Figure $17(\mathrm{a})$, the $\mathrm{Si}$ atoms can easily diffuse into the $\mathrm{Al}_{3} \mathrm{Zr}$ cells during the solidification process. The concentration of $\mathrm{Si}$ in the $\mathrm{Al}_{3} \mathrm{Zr}$ phase particle is a function of the temperature and the size of the formed $\mathrm{Al}_{3} \mathrm{Zr}$ phase particle. In other 


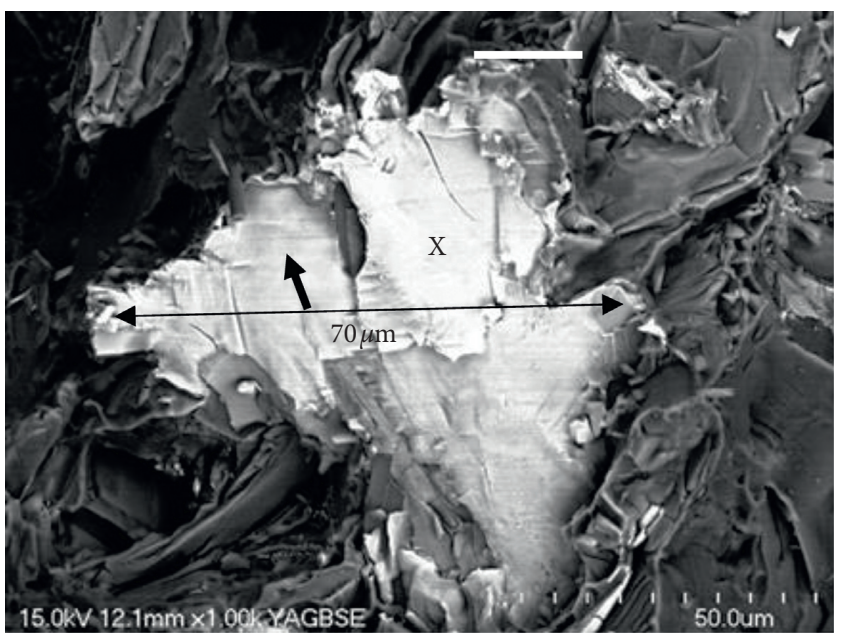

(a)

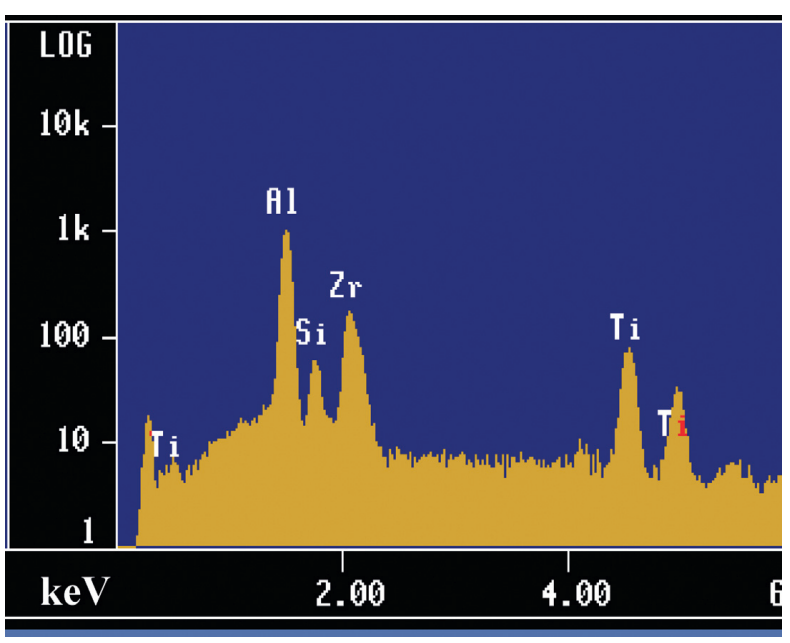

(b)

FIGURE 16: (a) Backscattered electron image of alloy F in the as-cast condition showing fracture of a massive Zr-rich phase, (b) EDS spectrum corresponding to the area marked $\mathrm{X}$ in $(\mathrm{b})$, indicating $(\mathrm{Al}, \mathrm{Si})_{3}(\mathrm{Zr}, \mathrm{Ti})$ phase.

TABle 4: Atomic radii of the main elements in $(\mathrm{Al}, \mathrm{Si})(\mathrm{Zr}, \mathrm{Ti})$ phases.

\begin{tabular}{lr}
\hline Element & Radius (nm) \\
\hline $\mathrm{Al}$ & 0.143 \\
$\mathrm{Si}$ & 0.117 \\
$\mathrm{Ti}$ & 0.145 \\
$\mathrm{Zr}$ & 0.160 \\
\hline
\end{tabular}

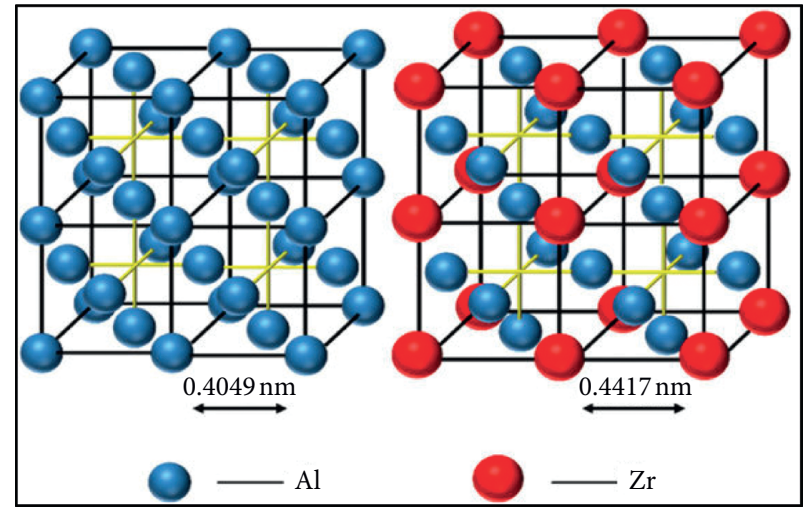

(a)

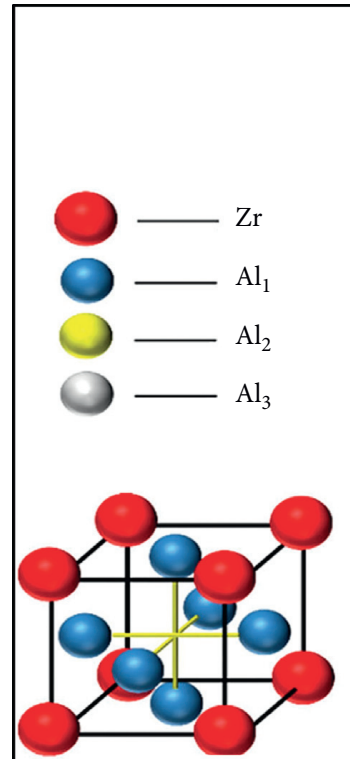

Cubic

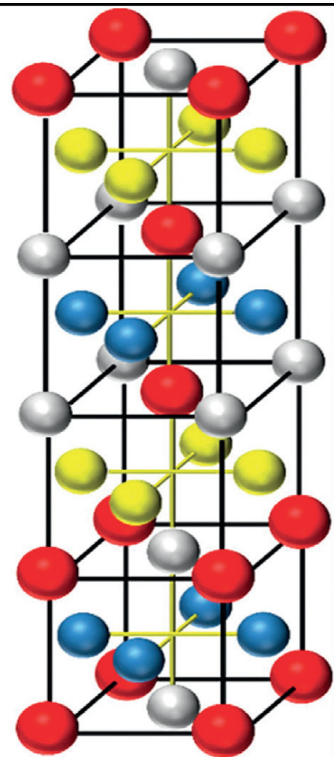

Tetragonal

(b)

Figure 17: Suggested crystal structures of $\mathrm{Al}_{3} \mathrm{Zr}[44,45]$. 
words, the larger the size of the $\mathrm{Al}_{3} \mathrm{Zr}$ phase particle, the lesser is the Si concentration, as shown in Figure 16(b). Considering the atomic radius of $\mathrm{Ti}(0.145 \mathrm{~nm})$ is very close to that of the $\mathrm{Al}$ atom $(0.143 \mathrm{~nm})$, this would facilitate the substitution of a certain number of $\mathrm{Al}$ atoms by $\mathrm{Ti}$ atoms.

\section{Conclusions}

Based on the results obtained in this study, the following conclusions may be drawn:

(1) There is no observable poisoning effect on the refinement of grain size after the addition of $\mathrm{Zr}$ to the alloys investigated in this study.

(2) The Si/Zr ratio varies depending on the size of $\mathrm{Zr}$ rich phase particles.

(3) The standard deviation (SD) of the UTS and \%El values is higher in $\mathrm{SiC}$ and $\mathrm{Al}_{2} \mathrm{O}_{3}$ particulate-containing alloys due to their low volume fraction and tendency for segregation.

(4) In order to achieve a lower SD, the volume fraction of $\mathrm{Al}_{2} \mathrm{O}_{3}$ or $\mathrm{SiC}$ particulates should be increased by an order of magnitude.

(5) The results show that, in all cases, $\mathrm{Al}_{2} \mathrm{Cu}$ phase is the main hardening agent. The contribution of about 1.5 vol.\% of $\mathrm{SiC}$ or $\mathrm{Al}_{2} \mathrm{O}_{3}$ particulates to the strength of the base alloy is higher than that those offered by $\mathrm{Zr}$ and Ni-based intermetallics.

(6) The reduction in mechanical properties due to addition of different elements is attributed principally to the increase in the percentage of intermetallic phases formed during solidification; such phase particles would act as stress concentrators, decreasing the alloy ductility.

\section{Data Availability}

Data will be available upon request.

\section{Conflicts of Interest}

There are no conflicts of interest between the authors.

\section{References}

[1] Y. Li and L. Arnberg, "Precipitation of dispersoids in DC-cast AA3103 alloy during heat treatment," in Essential Readings in Light Metals, J. F. Grandfield and D. G. Eskin, Eds., pp. 1021-1027, Springer, Cham, Switzerland, 2016.

[2] R. Srinivasan and M. A. Imam, "Role of dispersoids on the fatigue behavior of aluminum alloys: a review," in Fatigue of Materials III, T. S. Srivatsan, M. A. Imam, and R. Srinivasan, Eds., pp. 11-22, Springer, Cham, Switzerland, 2016.

[3] M. Tocci, R. Donnini, G. Angella, and A. Pola, "Effect of Cr and $\mathrm{Mn}$ addition and heat treatment on AlSi3Mg casting alloy," Materials Characterization, vol. 123, pp. 75-82, 2017.

[4] M. Remøe, I. Westermann, and K. Marthinsen, "Characterization of the density and spatial distribution of dispersoids in Al-Mg-Si alloys," Metals, vol. 9, no. 1, p. 26, 2019.
[5] N. C. W. Kuijpers, F. J. Vermolen, C. Vuik, P. T. G. Koenis, K. E. Nilsen, and S. v. d. Zwaag, "The dependence of the $\beta$-AlFeSi to $\alpha-\mathrm{Al}(\mathrm{FeMn}) \mathrm{Si}$ transformation kinetics in Al-Mg$\mathrm{Si}$ alloys on the alloying elements," Materials Science and Engineering: A, vol. 394, no. 1-2, pp. 9-19, 2005.

[6] T. Szymczak, G. Gumienny, L. Klimek, M. Goły, J. Szymszal, and T. Pacyniak, "Characteristics of Al-Si alloys with high melting point elements for high pressure die casting," $M a$ terials, vol. 13, no. 21, p. 4861, 2020.

[7] F. Hichem and G. Rebai, "Study of dispersoid particles in two $\mathrm{Al}-\mathrm{Mg}$-Si aluminium alloys and their effects on the recrystallization," Applied Physics A, vol. 119, no. 1, pp. 285-289, 2015.

[8] M. Kenyon, J. Robson, J. Fellowes, and Z. Liang, "Effect of dispersoids on the microstructure evolution in $\mathrm{Al}-\mathrm{Mg}-\mathrm{Si}$ alloys," Advanced Engineering Materials, vol. 21, pp. 1-7, 2019.

[9] T. Szymczak, J. Szymszal, and G. Gumienny, "Statistical methods used in the assessment of the influence of the Al-Si alloy's chemical composition on its properties," Archives of Foundry Engineering, vol. 18, pp. 203-211, 2018.

[10] T. Szymczak, J. Szymszal, and G. Gumienny, "Evaluation of the effect of the Cr, Mo, V and W content in an Al-Si alloy used for pressure casting on its proof stress," Archives of Foundry Engineering, vol. 18, pp. 105-111, 2018.

[11] T. Szymczak, J. Szymszal, and G. Gumienny, "Evaluation of the eect of Cr, Mo, V and W on the selected properties of silumins," Archives of Foundry Engineering, vol. 18, pp. 77-82, 2018.

[12] M. Cai, J. D. Robson, and G. W. Lorimer, "Simulation and control of dispersoids and dispersoid-free zones during homogenizing an AlMgSi alloy," Scripta Materialia, vol. 57, no. 7, pp. 603-606, 2007.

[13] K. Marthinsen, E. Nes, O. Daaland, and T. Furu, “The spatial distribution of nucleation sites and its effect on recrystallization kinetics in commercial aluminum alloys," Metallurgical and Materials Transactions A, vol. 34, no. 12, pp. 2705-2715, 2003.

[14] C. D. Marioara, S. J. Andersen, T. N. Stene et al., "The effect of $\mathrm{Cu}$ on precipitation in Al-Mg-Si alloys," Philosophical Magazine, vol. 87, no. 23, pp. 3385-3413, 2007.

[15] T. Marlaud, A. Deschamps, F. Bley, W. Lefebvre, and B. Baroux, "Influence of alloy composition and heat treatment on precipitate composition in Al-Zn-Mg-Cu alloys," Acta Materialia, vol. 58, no. 1, pp. 248-260, 2010.

[16] B. A. Szajewski, J. C. Crone, and J. Knap, "Analytic model for the Orowan dislocation-precipitate bypass mechanism," Materialia, vol. 11, p. 10067, 2020.

[17] S. Drouzy, Jacob, and M. Richard, "Interpretation of tensile results by means of quality index and probable yield strength," AFS International Cast Metals Journal, vol. 5, pp. 43-50, 1980.

[18] C. H. Cáceres, Microstructure Design and Heat Treatment Selection for Casting Alloys Using the Quality Index, ASMIMS, Cincinnati, OH, USA, 1999.

[19] C. H. Cáceres, T. Din, A. K. M. B. Rashid, and J. Campbell, "Effect of aging on quality index of an Al-Cu casting alloy," Materials Science and Technology, vol. 15, no. 6, pp. 711-716, 1999.

[20] C. H. Ca'ceres and J. A. Taylor, "Enhanced ductility in $\mathrm{Al}-\mathrm{Si}-\mathrm{Cu}-\mathrm{Mg}$ casting alloys with high Si content," in Shape Casting: The John Campbell Symposium, M. Tiryakiouglu and P. Crepeau, Eds., pp. 245-254, Los Angeles, CA, USA, 2005.

[21] I. El-Mahallawi, A. Shash, and A. Amer, "Nanoreinforced cast Al-Si alloys with $\mathrm{Al} 2 \mathrm{O} 3, \mathrm{TiO} 2$ and $\mathrm{ZrO} 2$ nanoparticles," Metals, vol. 5, no. 2, pp. 802-821, 2015. 
[22] T. Dorin1, M. Ramajayam, and T. J. Langan, "Effects of Mg, Si, And $\mathrm{Cu}$ on the formation of the Al3Sc/Al3Zr dispersoids," in Proceedings of the 16th International Aluminum Alloys Conference (ICAA16), Canadian Institute of Mining, Metallurgy \& Petroleum, Montreal, Canada, ISBN: 978-1-92687241-4, Montreal, Canada, June 2018.

[23] J. Hernandez-Sandoval, F. H. Samuel, and S. Valtierra, "Effect of additions of $\mathrm{SiC}$ and $\mathrm{Al}_{2} \mathrm{O}_{3}$ particulates on the microstructure and tensile properties of $\mathrm{Al}-\mathrm{Si}-\mathrm{Cu}-\mathrm{Mg}$ cast alloys," International Journal of Metalcasting, vol. 10, no. 3, pp. 253-263, 2016.

[24] G. H. Garza-Elizondo, A. M. Samuel, S. Valtierra, and F. H. Samuel, "Effect of transition metals on the tensile properties of 354 alloy: role of precipitation hardening," International Journal of Metalcasting, vol. 11, no. 3, pp. 413-427, 2017.

[25] G. H. Garza-Eiizondo, S. A. Alkahtani, A. M. Samuel, and F. H. Samuel, "Role of $\mathrm{Ni}$ and $\mathrm{Zr}$ in preserving the strength of 354 aluminum alloy at high temperature," in Light Metals 2014, pp. 305-314, Minerals, Metals and Materials Society, San Diego, CA, USA, 2014.

[26] H. R. Ammar, A. M. Samuel, F. H. Samuel, E. Simielli, G. K. Sigworth, and J. C. Lin, "Influence of aging parameters on the tensile properties and quality index of Al-9 pct Si-1.8 pct Cu-0.5 pct Mg 354-type casting alloys," Metallurgical and Materials Transactions A, vol. 43, no. 1, pp. 61-73, 2012.

[27] A. M. Samuel, F. H. Samuel, and H. W. Doty, "Influence of melt treatment and solidification parameters on the quality of 319.2 endchill aluminum castings," in 4th International Conference on Molten Aluminium Processing, pp. 261-293, Orlando, FL, USA, November 1995.

[28] J. Hernandez-Sandoval, A. M. Samuel, S. Valtierra, and F. H. Samuel, "Thermal analysis for detection of Zr-rich phases in Al-Si-Cu-Mg 354-type Alloys," International Journal of Metalcasting, vol. 11, no. 3, pp. 428-439, 2017.

[29] J. Campbell and M. Tiryakioğlu, "Review of effect of P and Sr on modification and porosity development in Al-Si alloys," Materials Science and Technology, vol. 26, no. 3, pp. 262-268, 2010.

[30] R. Fuoco, E. R. Correa, and A. V. O. Correa, "Effect of modification treatment on microporosity formation in $356 \mathrm{Al}$ alloy," AFS Transactions, vol. 103, pp. 379-387, 1995.

[31] D. Argo and J. E. Gruzleski, "Porosity in modified aluminum alloy castings,” AFS Transactions, vol. 96, pp. 65-74, 1988.

[32] H. W. Kerr, J. Cisse, and G. F. Bolling, "On equilibrium and non-equilibrium peritectic transformations," Acta Metallurgica, vol. 22, pp. 677-686, 1974.

[33] J. Murray, A. Peruzzi, and J. P. Abriata, "The Al-Zr (aluminum-zirconium) system," Journal of Phase Equilibria, vol. 13, no. 3, pp. 277-291, 1992.

[34] U. Ikhlaq, A. Hirose, R. Ahmad et al., "The role of Ar flow rates on synthesis of nanostructured zirconium nitride layer growth using plasma enhanced hot filament nitriding (PEHFN) technique," The European Physical Journal Applied Physics, vol. 69, no. 1, p. 10801, 2015.

[35] K. E. Knipling, D. C. Dunand, and D. N. Seidman, "Precipitation evolution in $\mathrm{Al}-\mathrm{Zr}$ and $\mathrm{Al}-\mathrm{Zr}$-Ti alloys during isothermal aging at $375-425^{\circ} \mathrm{C}$," Acta Materialia, vol. 56, no. 1, pp. 114-127, 2008.

[36] A. De Luca, S. Shua, and D. N. Seidman, "Effect of microadditions of Mn and Mo on dual L12- and $\alpha$-precipitation in a dilute Al-Zr-Sc-Er-Si alloy," Materials Characterization, vol. 169, pp. 114-127, 2020.
[37] H. Basoalto and M. Anderson, "An extension of mean-field coarsening theory to include particle coalescence using nearest-neighbour functions," Acta Materialia, vol. 117, pp. 122-134, 2016.

[38] J. Hernandez-Sandoval, G. H. Garza-Elizondo, A. M. Samuel, S. Valtiierra, and F. H. Samuel, "The ambient and high temperature deformation behavior of $\mathrm{Al}-\mathrm{Si}-\mathrm{Cu}-\mathrm{Mg}$ alloy with minor Ti, Zr, Ni additions," Materials \& Design, vol. 58, pp. 89-101, 2014.

[39] A. Rendtel, B. Moessner, and K. A. Schwetz, "Hardness and hardness determination in silicon carbide materials, book editor," Advances in Ceramic Armor, vol. 26, 2005.

[40] A. Daoud and W. Reif, "Influence of $\mathrm{Al} 2 \mathrm{O} 3$ particulate on the aging response of A356 Al-based composites," Journal of Materials Processing Technology, vol. 123, no. 2, pp. 313-318, 2002.

[41] A. M. Samuel, H. Liu, and F. H. Samuel, "Effect of melt, solidification and heat-treatment processing parameters on the properties of $\mathrm{Al}-\mathrm{Si}-\mathrm{Mg} / \mathrm{SiC}(\mathrm{p})$ composites," Journal of Materials Science, vol. 28, no. 24, pp. 6785-6798, 1993.

[42] O. Prach, O. Trudonoshyn, P. Randelzhofer, C. Körner, and K. Durst, "Effect of $\mathrm{Zr}, \mathrm{Cr}$ and Sc on the Al-Mg-Si-Mn highpressure die casting alloys," Materials Science and Engineering: $A$, vol. 759, pp. 603-612, 2019.

[43] G. H. Garza-Elizondo, A. M. Samuel, S. Valtierra, and F. H. Samuel, "Effect of $\mathrm{Ni}, \mathrm{Mn}, \mathrm{Sc}$, and $\mathrm{Zr}$ addition on the tensile properties of 354-type Alloys at ambient temperature," International Journal of Metalcasting, vol. 11, no. 3, pp. 396-412, 2017.

[44] R. L. Zhang, Experiential Electronic Theory of Solid and Molecules Changchun, Jilin Science and Technology Press, Changchun, China, 1993.

[45] J. D. Robson and P. B. Prangnell, "Dispersoid precipitation and process modelling in zirconium containing commercial aluminium alloys," Acta Materialia, vol. 49, no. 4, pp. 599-613, 2001. 